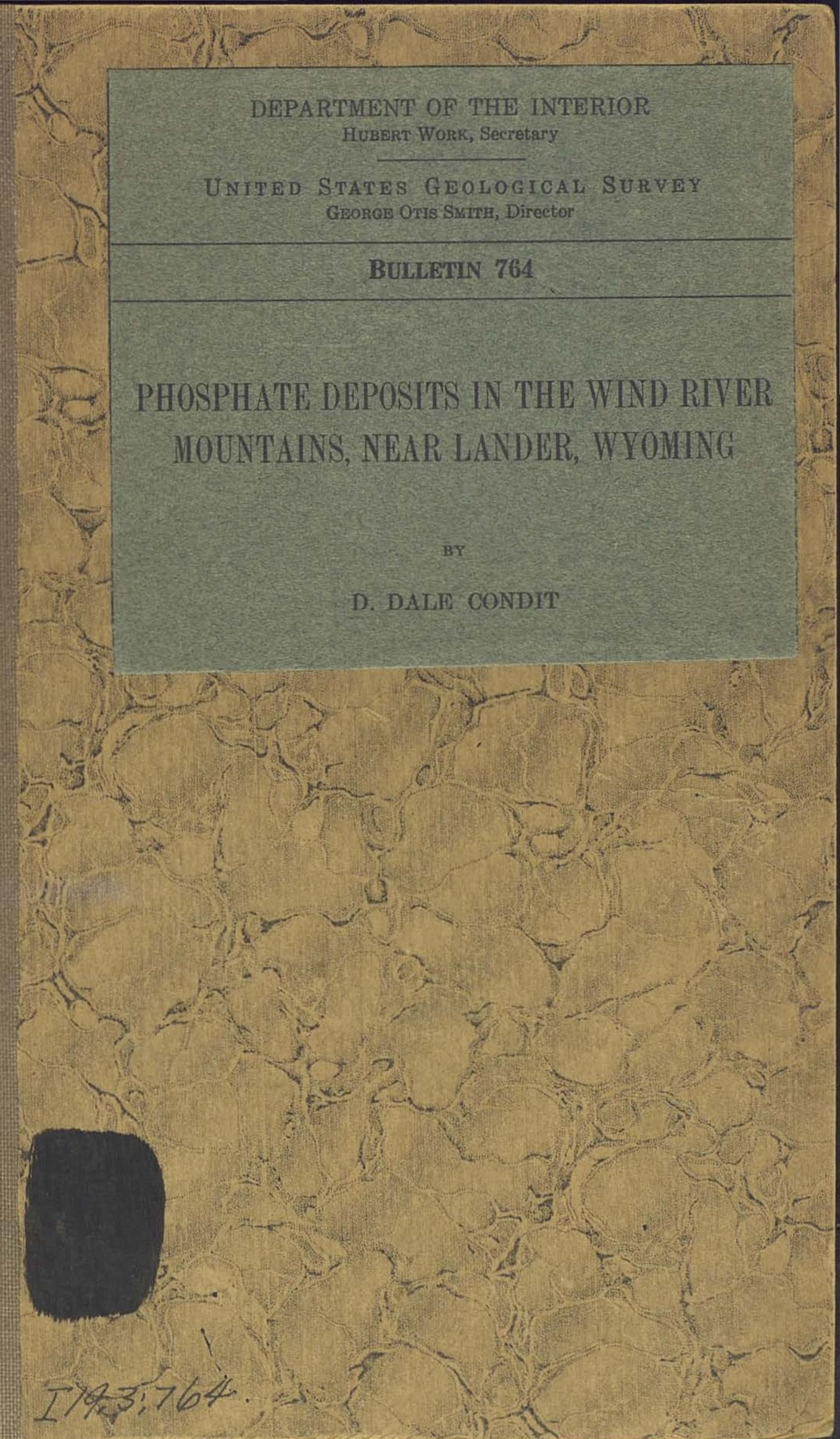





\section{DEPARTMENT OF THE INTERIOR \\ HUBERT WORK, Secretary \\ United States Geological Survey \\ George OTIS SMith, Director}

\section{Bulletin 764}

\section{PHOSPHATE DEPOSITS IN THE WIND RIVER MOUNTAINS, NEAR LANDER, WYOMING}

BY

D. DALE CONDIT

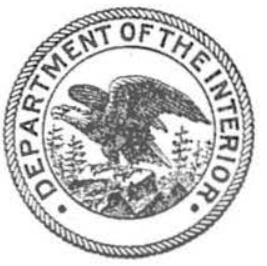

LIBTARX

TEXAS TECHNOLOGIFAL COLLEGE

LUBBOCK, TEXAS

WASHINGTON

GOVERNMENT PRINTING OFEICE

1924 
ADDITIONAL COPIES

OF THIS PUBLICATION MAY BE PROCURED FROM THE SUPERINTENDENT OF DOCUMENTS

GOVERNMENT PRINTING OFFICE

WASHINGTON, D. C.

AT

15. CENTS PER COPY 


\section{CONTENTS}

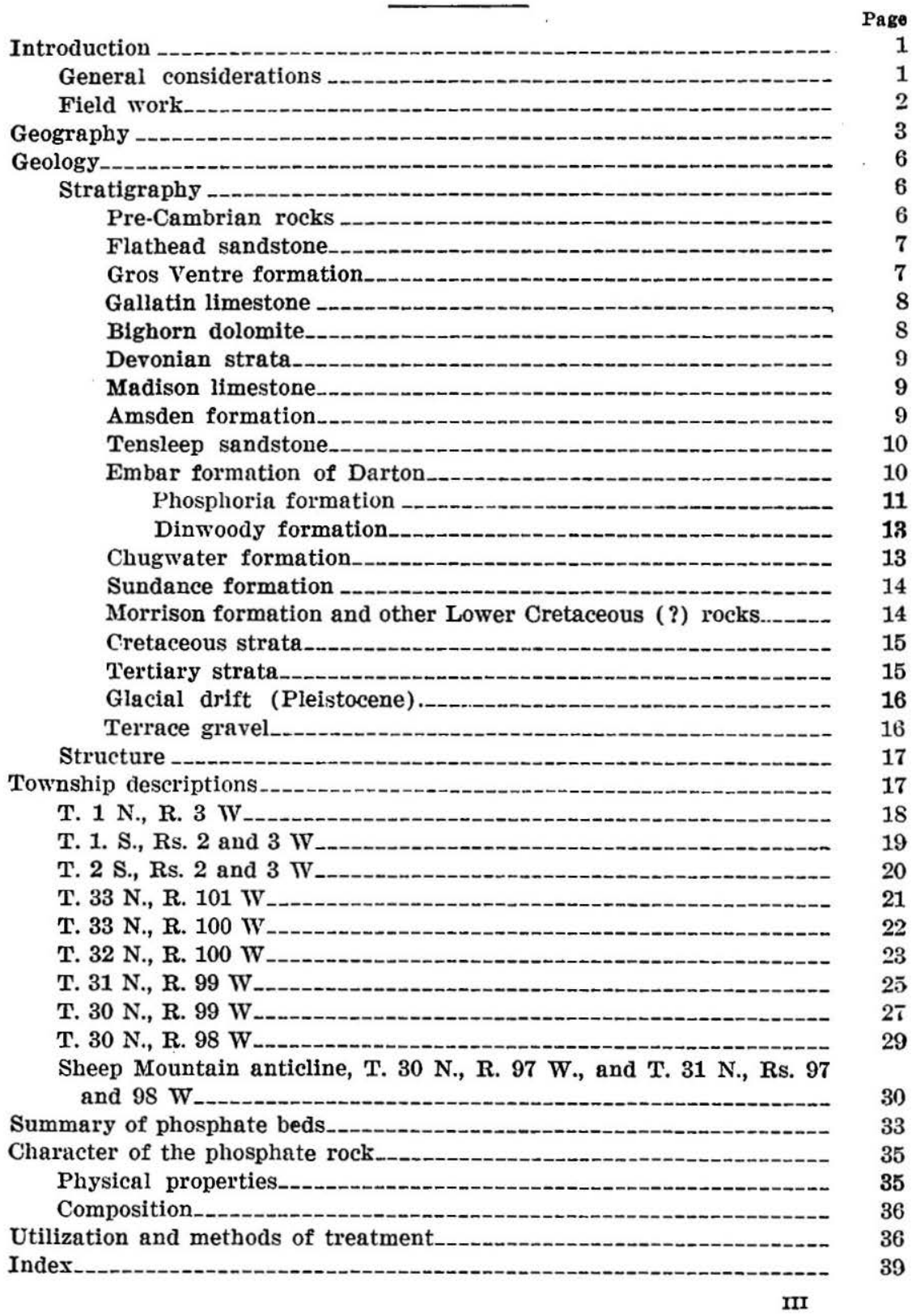





\section{ILLUSTRATIONS}

Pi.Ate I. A, View northeastward across Wind River Basin from slope of Wind River Range in T. 5 N., R. 6 W.; $B$, View eastward toward head of Red Creek canyon in T. 31 N., R. 99 W.

II. $A$, Exposures of Phosphoria formation in canyon of South Fork of Popo Agie River; $B$, Typical exposure of chert beds overlying upper phosphate beds on South Fork of Popo Agie River

Page

III. Geologic map of northeastern slope of Wind River Mountains near Lander

Figure 1. Index map showing coal, oil, and phosphate fields of west-central Wyoming and areas covered by publications of the Geological Survey concerning them 



\title{
PHOSPHATE DEPOSITS IN THE WIND RIVER MOUNTAINS NEAR LANDER, WYOMING
}

\author{
By D. Dale Condit
}

\section{INTRODUCTION}

\section{GENERAL CONSIDERATIONS}

The Rocky Mountain phosphate fields include beds of high-grade rock which underlie many thousands of square miles in Montana, Idaho, Wyoming, and Utah. The rock has been mined during the last several years at six or seven places, all within about 50 miles of Bear Lake, in southeastern Idaho and adjacent parts of Wyoming and Utah. The quantity of rock sold in 1920, the banner year, was 55,609 tons, but in 1922 it had dropped to 4,481 tons, although in that year 17,481 tons was actually produced. The output has never exceeded a small fraction of that of the entire United States, and the greater part of it has been shipped to California for treatment and use in that State by orchardists and gardeners as a strengthener of the soil.

In the Rocky Mountain States, where intensive cultivation has not yet been practiced to any considerable extent and where the arable lands are largely planted in alfalfa and other hay crops, the practice of using phosphate rock and other fertilizers has not yet become general, and the naturally rich soil has been made to produce the same crop year after year without restorative treatment. The depletion of the potash, phosphate, nitrogen, and other constituents of the soil that are essential to fertility is already noticeable in the wheat-producing areas, where there has been a progressive diminution in the yield per acre in recent years. The time is at hand when much of this land must be artificially renewed just as it has been renewed in the corn belt of the Mississippi Valley.

It is therefore opportune to call attention to the phosphate deposits in the Wind River Mountains, in west-central Wyoming (see fig. 1), which through their geographic position some 150 miles e'ast of the main barriers of the Rocky Mountains possess advantages over the phosphate deposits in Idaho in respect to transportation to the wheat belt of the Great Plains region. These deposits have the 
added advantage of being close to Lander, the terminus of the Chicago \& Northwestern Railway, which follows a direct, mostly downgrade route to the East and which is not alre'ady encumbered with transcontinental freight traffic. This line has ready access to the Burlington and other connecting railroads, which would facilitate ready distribution in all directions.

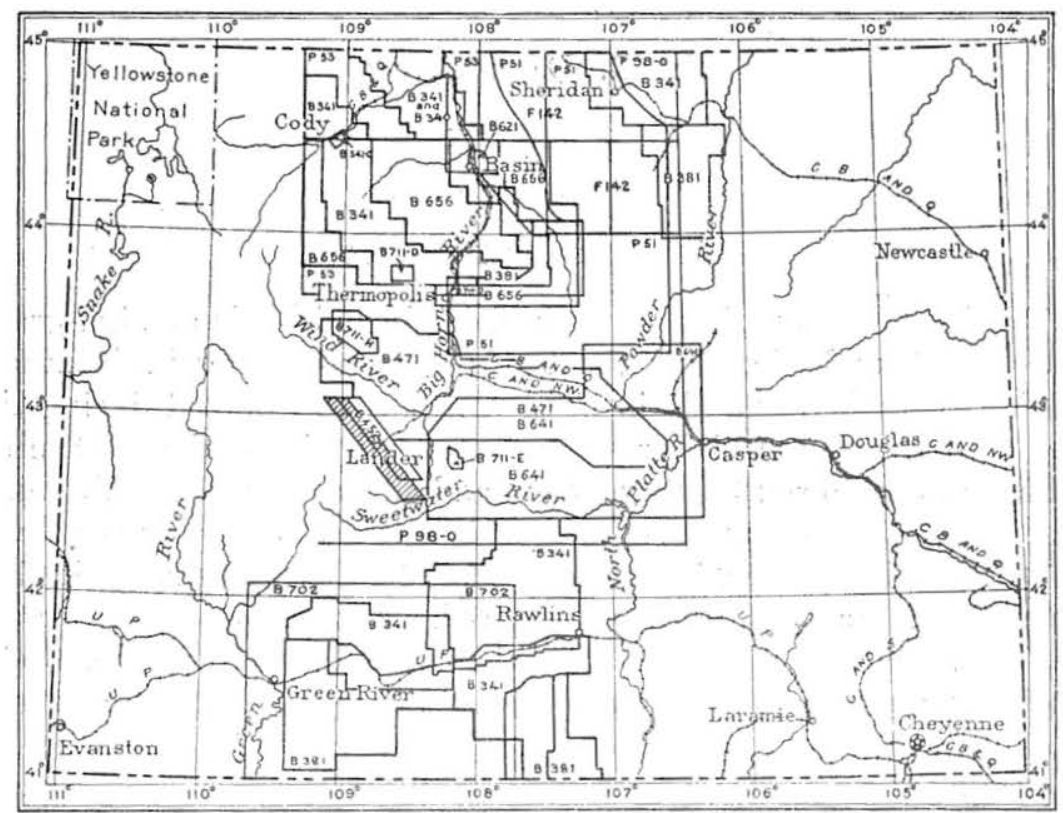

Figure 1.-Index map showing coal, ofl, and phosphate fields of west-central Wyoming and areas covered by publications of the United States Geological Survey concerning them. The area described in the present report is indicated by shading.

\section{FIETD WORK}

The field work upon which this report is based was done under the supervision of Eliot Blackwelder during the summer of 1913. The work was begun early in July in the vicinity of Dubois, at the upper end of Wind River Basin. There were two parties, one under Mr. Blackwelder, doing detailed work in the Owl Creek Mountains, and the other under the writer, following the northeast slope of the Wind River Range. In the work along the 50 miles of mountain front described in this report the writer was joined by A. R. Schultz, chairman of the phosphate committee of the land-classification board of the United States Geological Survey, whose able assistance greatly facilitated progress. In the early part of the season Hyrum Schneider was also a member of the party in the capacity of geologic aid. The examfnation of the Wind River Mountain front was completed 
about October 10, and the writer then took up the work in the Owl Creek Mountains, which was pushed until snow came the first week in December.

During the course of the work the members of these parties were treated with uniform courtesy by the residents of the districts. Among those to whom thanks are especially due for favors are Mr. N. H. Brown, of Lander, and officials of the Shoshone Indian Reservation at Fort Washakie.

The detailed work in 1913 was preceded by a reconnaissance survey by Eliot Blackwelder, who in 1910 visited a number of localities in the Wind River Range and collected data concerning the phosphate beds. ${ }^{1}$ In addition he made a study of the stratigraphy and other general geologic problems, some of which were discussed in a preliminary paper. ${ }^{2}$ In the description of the early Paleozoic stratigraphy the writer has made free use of the data in this paper.

\section{GEOGRAPHY}

The rugged topography of the Wind River Mountains is the result of somewhat advanced erosion of rocks that have been folded into a great anticline. Along the axis of this anticline the limestone, sandstone, and shale formations of the Paleozoic sequence have been entirely removed, laying bare the crystalline gneisses and schists, which rise in numerous snowy alpine peaks to an altitude of more than 13,000 feet. Toward the western part of the range, where the topography is most rugged, there are many small glaciers, whose grinding action on their rock floors contributes a rock powder to the mountain torrents, giving the water a milky appearance. The sedimentary formations overlap one another successively, in shingle-like fashion, the physiographically strong formations forming long dip slopes, which are furrowed at short intervals by sharp transverse canyons, most of which are occupied by permanent streams.

The basin topography of the Wind River valley may be said to begin with the "Red Beds," which rise in low hogback hills along the base of the mountains and are generally separated from the limestone dip slopes of the mountains by an inner lowland, commonly occupied by small streams parallel to the strike, such as Red Canyon Creek, a tributary to Little Popo Agie River from the south. From the "Red Beds" basinward there are successively lower hogback ridges formed by interbedded layers of Mesozoic sandstone and shale. The line of elongated anticlinal domes that extends from the vicinity of Fort Washakie southeastward past

1 Blackwelder, Eliot, A reconnaissance of the phosphate deposits in western Wyoming: U. S. Geol. Survey Bull. 470, pp. 452-481, 1911.

2 Blackwelder, Eliot, New geological formations in western Wyoming: Washington Acad. Sci. Jour., vol. 8, No. 13, pp. 417-426, 1918.

$5525-24-2$ 
Lander parallel to the mountains brings the "Red Beds" again to the surface and produces a characteristic topography.

At many places in Wind River Basin and well up the adjoining mountain slopes there are conspicuous gravel-covered terraces that denote different stages in the erosion of the basin. Table Mountain, near Lander, and the divide at the head of Red Canyon Creek, to the south, are examples of these terraces, being mesas cut on tilted strata and capped with coarse gravel. (See Pl. I, B.) Another mesa related to these is on the north side of North Fork of Little Wind River. These mesas, which range in altitude from 7,200 to 7,700 feet, are merely remnants of a once extensive plain over which were spread outwash deposits from the mountain front. Successively lower and lower terraces down to the present flood plain of Wind River are common in all parts of Wind River Basin. Their nearly level surfaces furnish excellent routes for wagon roads and can be followed for miles with only occasional interruptions produced by intrenched ravines.

As stated above, the highest peaks in the Wind River Range reach altitudes well above 13,000 feet. The adjacent part of the Wind River Basin ranges in height from about 5,000 to 6,000 feet. Lander stands a little less than 5,400 feet above sea level, and Fort Washakie at about the same altitude. The mouths of the canyons of the principal branches of Popo Agie and Little Wind rivers, where these streams issue from the mountains, are approximately 6,000 feet above sea level, and the fall averages about 100 feet to the mile for the first 8 miles downstream.

The principal streams issuing from the Wind River Range in the district are North and South forks of Little Wind River, North and Middle forks of Popo Agie River, and Little Popo Agie River. These are all large, swift streams that furnish an abundant supply of clear water, which is extensively used for irrigation. There are a number of smaller perennial streams, among which are Sage, Trout, Baldwin, Squaw, Willow, and Beaver creeks. Others are fair-sized brooks in their upper courses and sink into the ground a short distance away from the mountain front. Still others, such as Mill Creek, in T. 2 S., R. 2 W., have their sources in large springs that issue from limestone strata at the base of the mountains.

The climate of the Wind River region is semiarid, and the annual rainfall-about 15 inches near Lander-although greater than in many other parts of Wyoming, is not alone sufficient for the growth of crops of hay. Irrigation is therefore generally practiced. The North and South forks of Little Wind River and the several branches of Popo Agie River furnish a plentiful supply of water, which is put to good use along the spacious valley floors of those streams and on neighboring bench lands. Alfalfa and other hays, the principal 
crops, are used for the winter feed of thousands of cattle, which graze on the mountain slopes during the summer. In the higher parts of the region snow commonly falls during the later part of September and may be accompanied by severe cold, after which there is a month or so of mild weather during which the snow melts from the mountain slopes up to an altitude of perhaps 9,000 feet.

Lander, the principal town and the county seat of Fremont County, had in 1920 a population of 2,133. Hudson and Riverton are both prosperous villages, Hudson being the center of a coalmining industry and Riverton an important shipping and receiving point for Wind River Basin. The administrative headquarters for the Shoshone Indian Reservation are at Fort Washakie, near the center of the reservation, which occupies the area from Wind River south to the North Fork of Popo Agie River and from Riverton on the east to the vicinity of Circle, some 65 miles farther west.

The mining industry of the region consists chiefly of the production of coal, oil, natural gas, and gold. No attempt has been made to mine phosphate rock. Several coal mines have for years been in operation at Hudson, and the coal is shipped to different points. It is a subbituminous coal and is best suited for domestic use and as a steam coal in stationary boilers.

Seepages of oil at several points along the elongated domes near Fort Washakie, Lander, and Dallas were noticed by the early settlers, and the field has produced more or less oil continuously since 1883, when the first well was drilled. In recent years there has been considerable interest in the Pilot Butte and Maverick Springs domes, ${ }^{3}$ in the upper part of Wind River Basin, in both of which oil has been developed, and in the Derby dome, a short distance southeast of Dallas, where some oil has been obtained. The present production from the entire Lander district, embracing the Derby, Dallas, Lander, Pilot Butte, and Maverick Springs pools, does not exceed several hundred barrels of oil daily.

Gold has been mined in the Atlantic mining district, some 25 miles southeast of Lander, since early pioneer days, and the production to date is variously estimated at $\$ 1,000,000$ to $\$ 5,000,000$. In the early history of the district most of the gold came from placer deposits, but later the mining of lode deposits was begun. Mining operations have not been pushed vigorously in recent years, but there will be a great renewal of activity if transportation facilities are improved by the construction of a railroad along Sweetwater Valley.

The Chicago \& Northwestern Railway has its terminus at Lander, about 6 miles from the phosphate deposits of the adjacent mountain fronit. The line could be extended farther west up Wind River

see Collier, A. J., Anticlines near Maverick Springs, Fremont County, Wyo.: ס. $\mathbf{s}$ Geol. Survey Bull. 711, pp. 149-166, 1920. 
Basin, but it is highly improbable that a route will ever be sough. across the Continental Divide, to the west, which presents an unbroken mountainous front from 9,000 to more than 10,000 feet in altitude.

When the Union Pacific Railroad was planned many engineers regarded the Sweetwater route across South Pass, at the southeast end of the Wind River Mountains, as more favorable than the more southerly route that was finally adopted. It is possible that sometime either the Northwestern or the Burlington system will seek an entrance to Green River Basin by way of South Pass. With the extension of either of these lines the situation of the southeastern portion of the phosphate field as regards transportation would be improved.

Good wagon roads lead in all directions from Lander. Stages and mail leave daily for Fort Washakie and more remote points to the west and also for Atlantic, South Pass, and Pinedale. The road to Atlantic leads through Dallas, up Little Popo Agie River and Red Canyon, and across the bench lands adjoining Twin Creek. All the principal streams flowing from the mountains furnish easy natural routes which are followed by roads leading to the numerous ranches. At the base of the mountains the valleys suddenly contract to narrow canyons and most of the roads end, but a few continue farther up to give access to timber tracts.

The portion of the Wind River Range opposite Lander is included in the Washakie National Forest. Most of the canyon slopes are heavily timbered. The mountain front up to an altitude of 7,500 feet bears little timber, and the long limestone dip slopes are largely soil-covered and grassed. In the sheltered ravines thickets of quaking aspen and scattered pine and spruce are common. At higher altitudes the pine forest covers most of the surface, being densest on the north exposures.

\section{GEOLOGY}

\section{STRATIGRAPHY}

PRE-CAMBRIAN ROCKS

The pre-Cambrian rocks of the Wind River Range consist of a large variety of metamorphic and igneous rocks, of which no adequate study has yet been made. Among the oldest members of the complex are banded gneisses and mica schists into which have been intruded dikes of pegmatite and dikes and stocks of basic igneous rock. The structure is of the complex type common to such rock. It has been observed that in general the plane of schistosity or gneissoid banding trends roughly north, or nearly at right angles to the axis of the Wind River Range. 
Outcrops of pre-Cambrian rocks form a broad belt of high peaks extending the entire length of the Wind River Range. There are also small areas along the axis of the Sheep Mountain anticline in T. 30 N., R. 97 W. Farther east lie the Granite Mountains, a low range consisting of numerous scattered granite hills projecting above a plateau of flat-lying Tertiary beds.

Gneissoid granite cut by unaltered granite, which is in turn cut by pegmatite dikes, has been observed by Blackwelder in the northern part of the Wind River Range. Farther south dikes of diabase cutting granite were seen. In the Sweetwater mining district the country rock, a dark slaty schist, is believed by Knight ${ }^{4}$ to be Algonkian. It is very ferruginous and has zones of magnetite schist. Trap dikes are plentiful, and along and near them are the gold-bearing quartz veins that constitute the basis for the mining industry in the Sweetwater district.

The metamorphic complex is overlain by an essentially conformable sequence of rocks ranging in age from Middle Cambrian to Upper Cretaceous. The Paleozoic strata alone have a thickness of nearly 4,000 feet, and the overlying Mesozoic strata as found in the Wind River Basin are probably 10,000 feet thick. The oldest of this long sequence of sedimentary rocks is the Flathead sandstone, of Middle Cambrian age. The Cambrian and younger rocks are essentially unmetamorphosed.

\section{FLATHEAD SANDSTONE}

The Flathead sandstone (Middle Cambrian) consists largely of gray or brown shaly sandstone and micaceous sandy shale, with several beds of brown quartzitic sandstone. As a whole it is a comparatively weak formation, and complete outcrops of it are rare. Few fossils have been found in it, and the commonest forms are black oboloid brachiopods. The formation averages about 300 feet in thickness and over large areas contains one or more members of chocolate-brown quartzitic conglomerate.

\section{GROS VENTRE FORMATION}

The Flathead sandstone grades up into a series of clay shales with alternate beds of limestone and calcareous shale, which together constitute the Gros Ventre formation (Middle Cambrian). In Bea Ogwa Canyon this formation appears to be about 600 feet thick; in the Wind River Range it may be slightly less. The shales are

- Knight, W. O., The Sweetwater mining district, Fremont County, Wyo.: Wyoming Univ. Bull., 1901. See also Spencer, A. C., The Atlantic gold district and the North Laramie Mountains, Fremont, Converse, and Albany counties, Wyo.: U. S. Geol. Survey Bull. 626, 1916.

s Blackweller, Eliot, New geological formations in western Wyoming: Washington Acad. Scl. Jour., vol. 8, pp. 417-419. 1918. 
grayish to green and range from distinctly sandy shale near the base to highly calcareous shale near the top. The interbedded limestones are generally gray, more or less mottled with olive and ocher colors. Many of the beds contain black oolitic granules, and others consist of "edgewise" conglomerate. Some of the limestone beds contain fragmentary Middle Cambrian trilobites, but on the whole fossils are not abundant. Complete exposures of the formation are rare, because the shale beds are generally concealed by soil and vegetation, leaving only the more massive limestone beds protruding as ledges and reefs.

\section{GALIATIN IIMESTONE}

Although limestone predominates in the Gallatin formation (Upper Cambrian), there is more or less shale and sandstone in the middle portion. In the northwestern part of the Wind River Range the terrane is 250 feet thick, but toward the southeast it appears to become somewhat thinner. At the base is a massive, finely crystalline limestone of dark-gray color clouded with brown. On close examination it is found to be filled with little sepia-brown oolitic granules about the size of mustard seed. This lower member is 20 to 100 feet thick. The middle member is generally thin bedded and contains layers of gray calcareous shale and buff sandstone. "Edgewise conglomerate" thickly sprinkled with glauconite grains is characteristic of this member. The uppermost member is relatively thin bedded and contains a little shale. The rock is dolomitic and more or less siliceous, with thin laminae of chert. Some layers ere richly fossiliferous.

\section{BIGHORN DOLOMITE}

The thin-bedded Gallatin limestone is overlain by the Ordovician Bighorn dolomite. The lower part is massive, cream-colored to nearly white, and of saccharoidal texture. Its weathered surfaces are very rough and pitted. Above the massive dolomite are thin beds of dolomitic rock which, as exposed in Dinwoody Canyon, have a thickness of about 30 feet. Fossils are fairly plentiful in both the upper thin-bedded portion and in the massive lower portion, and on the evidence they afford the formation has been referred to the Ordovician.

At the north end of the Wind River Mountains the Bighorn is 300 feet thick, and some of the individual massive beds are 25 feet thick. Toward the south the formation thins, and in a section in the canyon of Middle Fork of Popo Agie River near Lander it is 163 feet thick. Beneath the dolomite is locally a bed of sandstone containing fossils of the large cephalopod Endoceras. 
There is but little record of unconformity at the base of the Bighorn, but at the top the evidence is clearly recorded by solution caverns, an undulating contact, and general unconformable relations with the overlying Devonian strata.

DEVONIAN STRATA

In the northern part of the Wind River Range the Bighorn dolomite is separated from the Madison limestone above by a few feet of limestone containing Devonian fossils. In Dinwoody Canyon strata of this age are only 5 feet thick, but toward the west they thicken to several hundred feet in the Teton Range, where the name "Darby formation" has been applied to the beds by Blackwelder. ${ }^{B}$

\section{MADISON LIMESTONE}

Few formations in Wyoming are more easily recognized than the Madison limestone (Mississippian). It consists almost entirely of dark-gray limestones, in general plentifully fossiliferous. Where adequately exposed it produces high cliffs and mountainous ridges. At the west end of the Wind River Range it is nearly 800 feet thick, but toward the southeast it gradually thins, being about 500 feet thick in the vicinity of Lander and still thinner beyond that town.

The formation consists of alternating thick and thin beds of gray limestone with a few layers of brownish-gray dolomite and a small amount of calcareous shale. Some of the limestone beds are 20 to 30 feet thick; others are thin slabs. This variation in thickness gives the outcrop in many places the aspect of a series of huge steps. The thicker beds are usually rather light gray or lead-colored limestone of dense texture. Chert is not characteristic of the Madison but commonly appears in black or dark-gray nodules.

\section{AMSDEN FORMATION}

The Amsden, which is probably all late Mississippian in this area, is a relatively weak member of the Paleozoic sequence that generally occupies slopes and hollows between the cliffs and ridges of the underlying Madison limestone and the overlying Tensleep sandstone. Exposures of the softer beds are not common, and complete sections of the formation can be observed only in the most favorable places. Throughout western Wyoming the formation is readily divisible into a lower sandstone member and an upper shale and dolomite member.

The lower member is a cream-colored calcareous sandstone averaging 30 to 50 feet in thickness but apparently only 20 feet thick near Lander. Cross-bedding is characteristic of the sandstone.

- Blackwelder, Eliot, New geological formations in western Wyoming: Washington Acad. Scl. Jour., vol. 8, pp. 417-426, 1918. 
The lower sandstone member is separated from the somewhat similar Tensleep sandstone above by 50 to 75 feet of alternating shale, sandstone, and dolomite. Near the base of this sequence there is generally 10 to 15 feet of dark-red marly limestone or shale cons taining small nodules of hematite. Fossils are fairly plentiful in the Amsden formation, but in most localities they are too poorly preserved to be clearly identifiable. In this area the beds all appear to be of late Mississippian age, to judge from fossils collected by Branson " in the Little Popo Agie region and at Bull Lake, a short distance to the north, but farther east in Wyoming the Amsden has yielded Pennsylvanian fossils and has been regarded as chiefly of Pennsylvanian age.

\section{TENSLEEP SANDSTONE}

The Tensleep sandstone (Pennsylvanian) is a massive resistant formation which reveals itself in hogback ridges and cliffs. Its thickness ranges from 300 to 450 feet and is greatest opposite Fort Washakie, the formation thinning both to the northwest and the southeast. It consists almost entirely of fine-grained friable white and buff sandstone. Many of the layers are distinctly calcareous, but others have been cemented into quartzite. Nearly all the strata are regularly cross-bedded, and the laminae are in most places inclined toward the southwest. Fossils are rare, but a few marine mollusks have been found in calcareous beds in the Big Horn Mountains.

\section{EMBAR FORMATION OF DARTON}

Strata 300 to 500 feet thick lying between the Tensleep sandstone and Chugwater red beds in west-central Wyoming were designated the Embar formation by Darton. ${ }^{8}$ The strata contain phosphate rock in the Wind River and Owl Creek mountains. In Wind River Basin, where they lie under cover, they are a source of oil and gas. Blackwelder, ${ }^{9}$ as a result of studies of the Wind River Mountains, found it desirable to divide the Embar into two formations, because the rocks included are so different in character and cover so large a geologic range. To the upper shaly part, of Triassic age, he applied the name Dinwoody formation, from exposures in Dinwoody Canyon, in the Wind River Mountains; and to the lower part, consisting largely of limestone and calcareous shales, he applied the name Park City formation, on account of their equivalence to beds of

${ }^{7}$ Branson, E. B., and Greger, D. K., Amsden formation of the east slope of the Wind River Mountains of Wyoming and its fauna: Geol. Soc. America Bull., vol. 29, pp. 307$326,1918$.

${ }^{8}$ Darton, N. H., Geology of the Bighorn Mountains: U. S. Geol. Survey Prof. Paper 51. p. $35,1906$.

B Blackwelder, Eliot, New geological formations in western Wyoming: Washington Acad. Sci. Jour., vol. 8, pp. 417-426, 1918. 


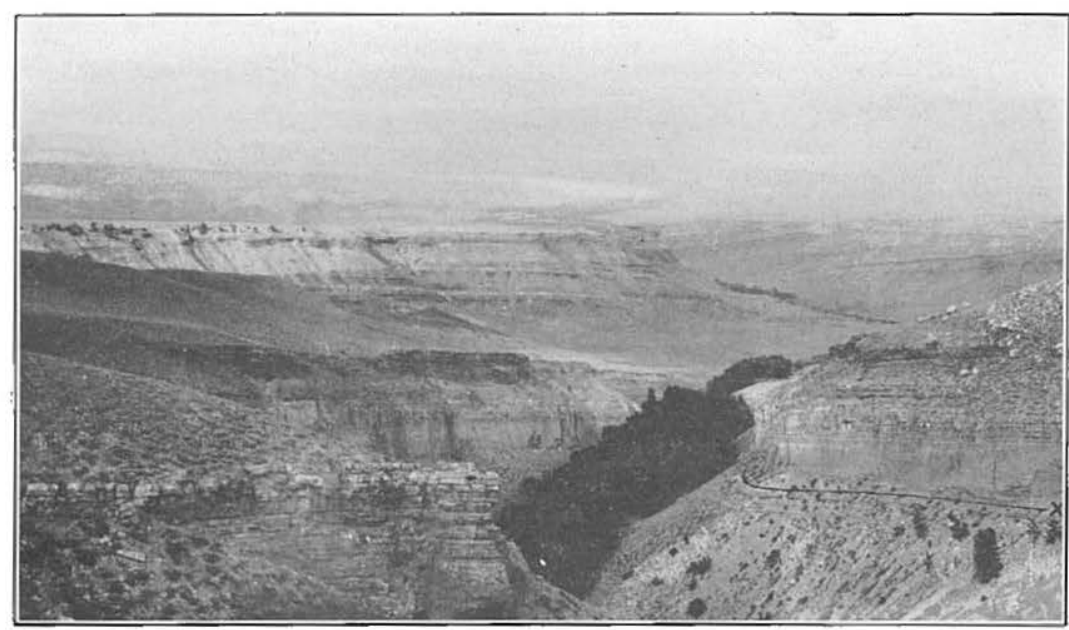

A. VIEW NORTHEASTWARD ACROSS WIND RIVER BASIN FROM SIOPE OF WIND RIVER RANGE IN T. 5 N., R. 6 W.

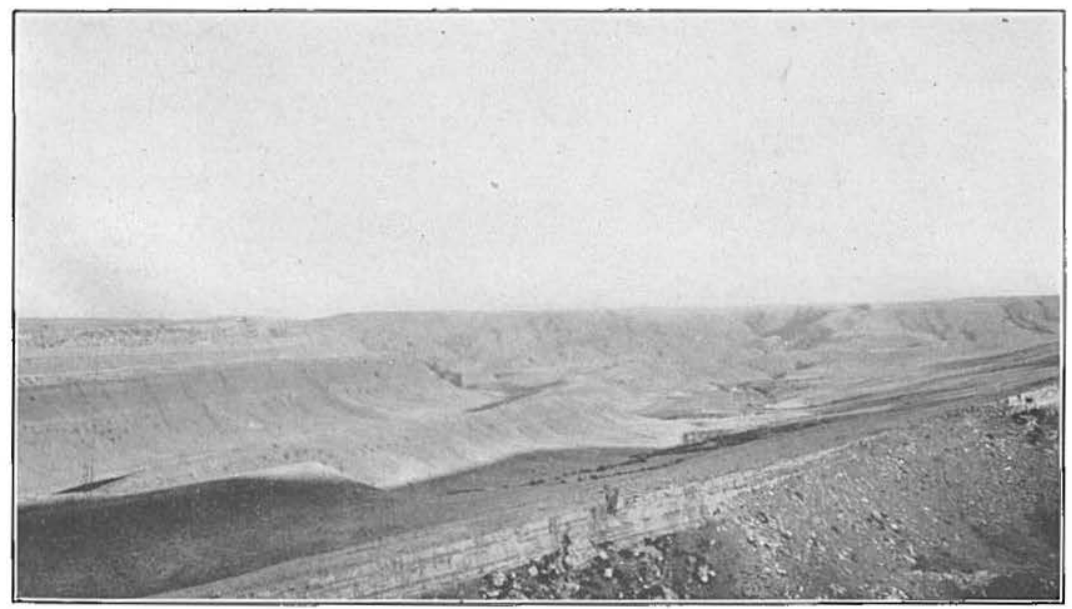

B. VIEW EASTWARD TOWARD HEAD OF RED CREEK CANYON IN T. 31 N., R. $99 \mathrm{~W}$. 


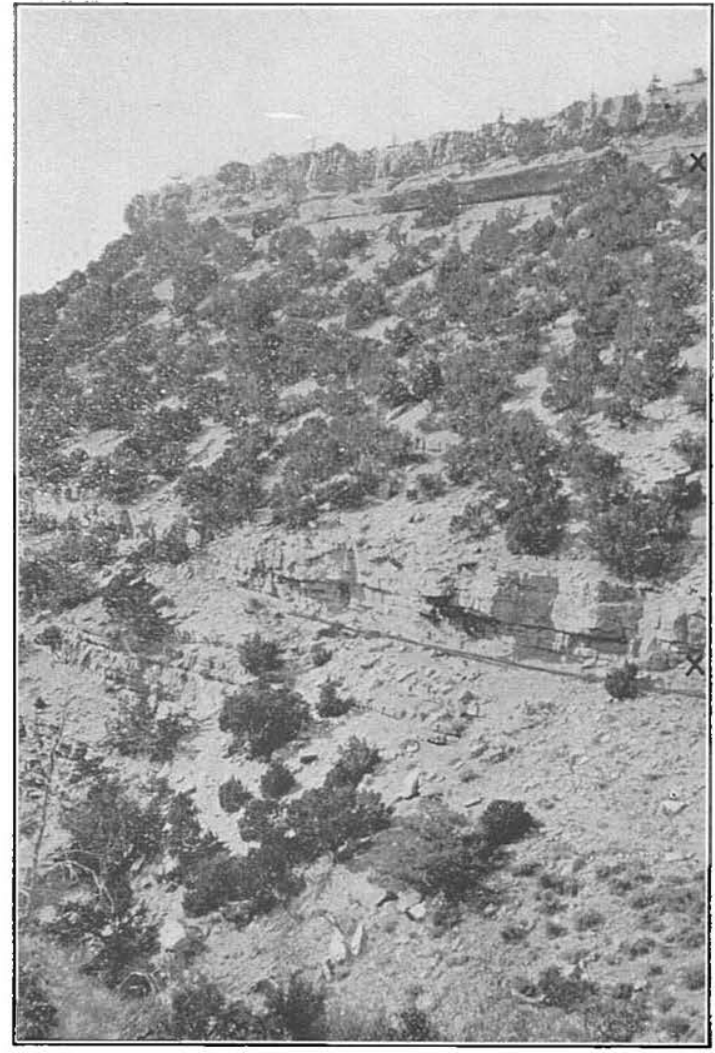

A. EXPOSURES OF PHOSPHORIA FORMATION $(X$ IN CANYON OF SOUTH FORK OF POPO AGIE RIVER

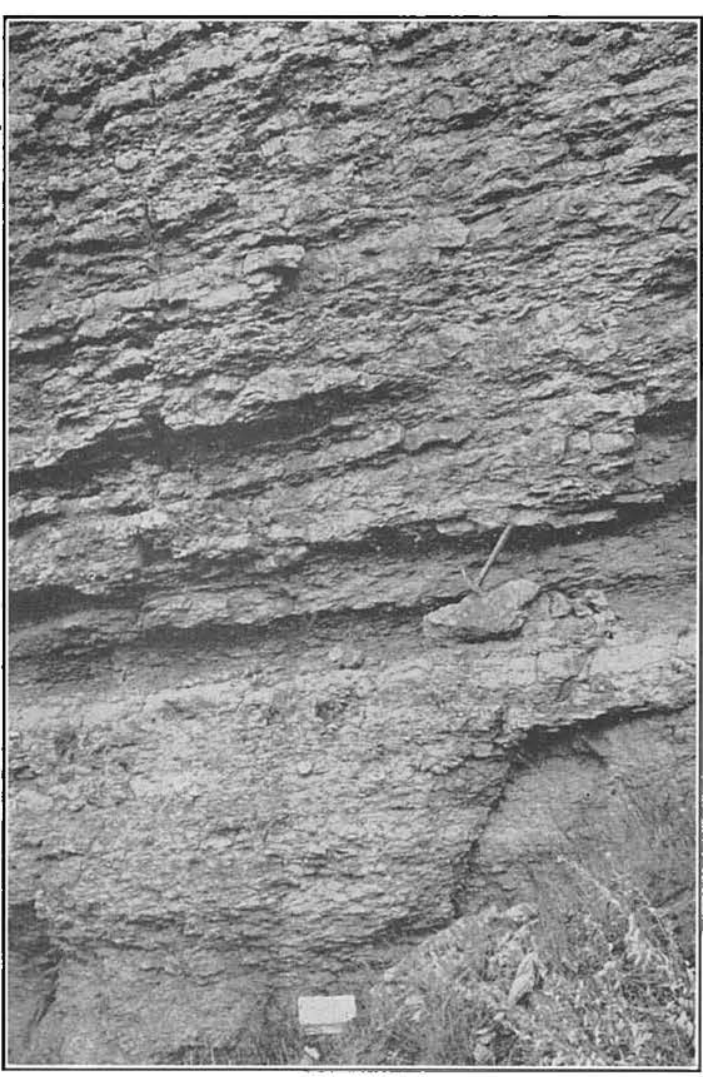

$B$. TYPICAL EXPOSURE OF CHERT BEDS OVERLYING UPPER PHOSPHATE BEDS ON SOUTH FORK 
that name in northeastern Utah. Later studies, by several workers, have proved that the part of the Embar beneath the Dinwoody formation corresponds to only the upper or Phosphoria part of the Park City formation of Utah, and the United States Geological Șurvey now designates this lower part of the Embar of western Wyoming as Phosphoria formation, instead of Park City formation.

\section{PHOSPHORIA FORMATION}

The Phosphoria, of Permian age, is the great phosphate-bearing formation of the Rocky Mountain region and contains the valuable beds mined on a commercial scale in western Wyoming, southeastern Idaho, and northward across Yellowstone Park in southern Montana. It corresponds to the upper portion of the Park City formation of northeastern Utah.

In the Wind River Mountains the Phosphoria formation is 200 to 300 feet thick. The upper part may be divided into three rather distinct members, which are recognizable not only throughout the Wind River Range but as far west as Idaho. For reasons set forth below these members are appropriately called the upper bryozoanbearing limestone, the phosphatic shale, and the lower bryozoanbearing limestone. The underlying beds are so variable that subdivisions which might be made for one section would not apply well in adjacent sections. Below is a representative section of the Phosphoria formation, measured on South Fork of Little Wind River:

\section{Section of Phosphoria formation on South Fork of Little Wind River}

Upper bryozoan-bearing limestone:

Limestone, chalky in upper portion, dolomitic and cherty, grayish below

Ft. in.

Limestone, brownish gray, crystalline, fossiliferous; Leioclema, Fenestella, Spiriferina pulchra, Derbya, and small crinoid segments plentiful

Chert, nodular, in bluish-gray shaly matrix

Shale, siliceous, bluish gray and cherty near top, drab to sepia-brown, with phosphate bands, in lower part_..-.Upper phosphate bed:

Phosphate, dark, oolitic, sandy; Pugnax only fossil recognized (tricalcium phosphate, 41.14 per cent) ---

Phosphate, sandy; Productus nevadensis and Pugnax common (tricalcium phosphate, 43.74 per cent) _.....

Lower bryozoan-bearing limestone:

Limestone, brownish gray, thin bedded; Productus nevadensis and Spirifer aff. S. cameratus plentiful. In the lower portion are abundant specimens of Chonetes aff. C. geinit ianus

Limestone, massive, yellowish brown, crystalline; many fossils, Leioclema especially abundant. 
Limestone, dolomitic, interbedded with laminated chert and sandy shale

Limestone, gray, coarsely crystalline, massive; abundant molds of diminutive pelecypods and gastropods_..--_-_-

Lower phosphate bed:

Limestone, phosphatic, gray, with dark spots; Lingulidiscina utahensis present

Phosphate rock, calcareous, dark, granular (tricalcium phosphate, 36.51 per cent)

Limestone, phosphatic, dense textured, dark; a fossil, probably Composita, present

Phosphate rock, calcareous; green granules of glauconite (?) abundant; phosphatic shells of Lingulidiscina abound (tricalcium phosphate, 48.13 per cent)

Phosphate rock, dark, calcareous; few traces of fossils (tricalcium phosphate, 39.92 per cent)

Limestone, granular, thick bedded, having small calcite vugs; granules of glauconite (?) present

Limestone and dolomite, argillaceous, gray, with cherty layers and localized green stains

Chert, white and gray, laminated.

Limestone, buff, dolomitic, resting on Tensleep sandstone

Fossils have been found in each of the four principal divisions of the Phosphoria formation. The upper bryozoan-bearing limestone has abundant large specimens of the bryozoan Leioclema and the brachiopods Derbya sp. and Spiriferina pulchra. In the phosphatic shale underlying this limestone fossils are rare, but the following have been identified by G. H. Girty from material collected in the principal bed of phosphate at the base of the shale:

\section{Nucula? sp.}

Pleurotomaria? sp.

Productus nevadensis.

Productus subhọridus.

The lower bryozoan-bearing limestone contains abundant fossils everywhere, the most prominent being Leioclema and Spiriferina pulchra. Chonetes aff. C. geinitzianus is also plentiful in a few places.

The upper bryozoan-bearing limestone is variable in detail but is a prominent, easily recognized member throughout the district. Along the northeast slope of the Wind River Range it consists generally of massive gray to cream-colored limestone 30 to 60 feet thick, underlain by greenish nodular chert in a matrix of shale. The rock becomes more dolomitic toward the south end of the range, and the fossils are not so well preserved. It is prominent as a controlling factor in the topography of both the Wind River and the Owl Creek mountains and produces long faceted dip slopes along the mountain front. 
The phosphatic shale is probably the most distinctive member of the Phosphoria formation. On the north slope of the Wind River Range it consists of sepia-brown to nearly black shale 20 to 40 feet thick, more or less cherty in the upper portion. It is for the most part notably fissile and has bands of limestone and oolitic phosphate and at the base the upper or Productus-bearing phosphate bed.

The lower bryozoan-bearing limestone lies beneath the phosphatic shales and is a little above the middle of the formation. It is grayish to brown and becomes distinctly darker and more phosphatic toward the top. In addition to Bryozoa it commonly contains many comminuted fossil fragments, large brachiopods, green granules possibly of glauconite, and scattered foraminiferal shells.

The lowest division of the Phosphoria, although more variable than the other members, generally consists of two shaly zones, each underlain by beds of dolomite, sandstone, and chert. The shales are yellowish to greenish, and the lower shale zone especially contains much chert in the form of thin greenish laminae and locally large geodes of calcite. About 50 feet above the Tensleep sandstone is a massive gray limestone ledge, beneath which is a phosphate bed filled with the disk-shaped shells of Lingulidiscina utahensis (also known as Orbiculoidea utahensis). This bed is recognizable throughout the Wind River Range and at a number of places has been found to contain fossil fish, collections of which are described by Branson. ${ }^{10}$

\section{DINWOODY FORALATION}

The highly fossiliferous Phosphoria strata are overlain by the Dinwoody formation (Triassic), a series of shale and shaly limestone which yield few satisfactory fossils but nevertheless have characteristics so distinctive as to be easily recognized wherever they are exposed. Typically the Dinwoody formation consists of greenish-gray shale alternating with thin slabs of dense calcareous sandstone or sandy limestone of greenish-gray color that weathers to a deep brown. Near the top the beds are more argillaceous and locally contain more or less gypsum. The thickness is 150 to 200 feet in the northwestern. part of the Wind River Mountains and gradually diminishes eastward, being 70 feet at Bea Ogwa Canyon and 30 feet at Sheep Mountain, south of Lander.

\section{CHUGWATER FORMATION}

No formation in the region is so conspicuous and so easily recognized as the Triassic Chugwater red beds. With a fairly uniform thickness of 1,200 to 1,450 feet they skirt the northeast slope of the

${ }^{10}$ Branson, E. B., The lower Embar of Wyoming and its fauna: Jour. Geology, vol. 24, pp. 638-664, 1916. 
Wind River Range and the Rattlesnake Mountains, to the east. The same formation extends around the Owl Creek uplift, where it is only a little thinner than in the Wind River Range. At first glance the Chugwater appears to consist of a monotonous sequence of shaly red sandstones and sandy shales, but more detailed examination shows that there is much variety and individuality in detail. Like red beds in general, the Chugwater is sparingly fossiliferous, though bits of silicified wood, vertebrate bones, and mollusks have been found in it. In the lower third of the formation shale predominates and exposures are much less common than in the upper beds. The shales are slightly micaceous and contain a large admixture of very fine sand which imparts to the rock an earthy texture. The prevailing colors are brick-red to chocolate, with a few thin beds and blotches of greenish gray. The red shales grade upward into a somewhat similar sequence about 400 feet thick, in which sandstone predominates and which is more prominently exposed. There are generally one or two beds of hard gray nonfossiliferous limestone. The middle sandstone is overlain by a weaker zone of shale, clay, and sandstone with thin layers of limestone. Above this shaly portion is about 150 feet of orange-colored massive sandstone, the most resistant member of the formation. The highest member is weak shale, generally not exposed. It has beds of massive snow-white gypsum, 25 to $\check{0} 0$ feet thick or locally even thicker.

\section{SUNDANCE FORMATION}

The Chugwater red beds are overlain by the gray or greenish shale beds of the Sundance formation (Upper Jurassic). The lower half of this formation contains many beds of limestone, which grade upward into a calcareous clay with thin beds of sandy limestone. At many horizons are found shells of Gryphaea calceola and Belemnites densus. At the top of the formation is sandstone which has no fossils and might well be included in the Morrison formation. The thickness of the Sundance is 200 to 300 feet; it is greatest at the west end of the region and decreases toward the east.

\section{MORRISON FORMATION AND OTHER LOWER CRETACEOUS (?) ROCKS}

Over the fossiliferous Jurassic beds and upper sandstone member is a weak series of soft clay shales and interbedded sandstones with local beds of fresh-water limestone representing the Morrison formation (Cretaceous?) and overlying Lower Cretaceous (?) rocks. Gray and lavender colors predominate, but there are many broad and narrow stripes of maroon, pink, olive, green, purple, russet, and white. Fer distinctive fossils have been found in these rocks in the Lander region. The thickness is 300 to 400 feet. 
CRETACEOUS STRATA

The strata of known Cretaceous age exposed in the Wind River Basin form a sequence more than 8,000 feet thick and include valuable beds of coal and sandstones that yield oil and gas. Below is a table showing the classification of the strata as described by Woodruff and Winchester. ${ }^{11}$

Geologic relation of the Upper Cretaceous formations in the IVind River region

\begin{tabular}{|c|c|c|c|c|}
\hline System & Series & Group & Formation & Character \\
\hline \multirow{2}{*}{ Tertiary. } & \multirow{2}{*}{ Eocene. } & & \multirow{2}{*}{$\begin{array}{l}\text { Wind River } C \text { or- } \\
\text { mation. } \\
\text {-Unconformity- } \\
\text { Fort Union forma- } \\
\text { tion. }\end{array}$} & $\begin{array}{l}\text { Banded sandy shale, sandstone, and } \\
\text { conglomerate. }\end{array}$ \\
\hline & & & & $\begin{array}{l}\text { Sandstone and sandy shale, with beds } \\
\text { of coal. }\end{array}$ \\
\hline \multirow{4}{*}{ Oretaceous. } & \multirow{4}{*}{ Upper Cretaceous. } & \multirow{3}{*}{ Montana } & \multirow{2}{*}{$\begin{array}{l}\text { Mesa verde forma- } \\
\text { tion. }\end{array}$} & $\begin{array}{l}\text { Tan-colored sandy shale and a few } \\
\text { sandstone lenses, with beds of coal. }\end{array}$ \\
\hline & & & & $\begin{array}{l}\text { Slightly ferruginous sandstone and a } \\
\text { small amount of sandy shale with } \\
\text { beds of coal. }\end{array}$ \\
\hline & & & \multirow[t]{2}{*}{ Mancos shale. } & \multirow{2}{*}{$\begin{array}{l}\text { Thick beds of tan-colored sandy shale, } \\
\text { shaly sandstone, and local lenses of } \\
\text { massive sandstone. Only the upper } \\
\text { part exposed in the coal felds. }\end{array}$} \\
\hline & & Colorado & & \\
\hline
\end{tabular}

In the eastern part of the Wind River Basin is a prominent sandstone with associated shale 150 to 200 feet thick, overlying the variegated Morrison shales. This includes the Dakota sandstone, the basal formation of the Upper Cretaceous. Westward the sandstone disappears, and the horizon is occupied by dark olive-colored shales.

Over the Dakota sandstone is a thick sequence of marine shales with a few beds of sandstone. Woodruff ${ }^{12}$ describes this formation as the Mancos shale and states that the thickness is more than 6,000 feet. In general the formation is characterized by dull-gray to sooty-black shales which contain cycloid fish scales. In the upper part of the black-shale zone are beds of a peculiar yellow clay known as bentonite. The formation contains a few thin coal beds of little economic importance. The valuable coal beds of this part of Wyoming lie in the Mesaverde formation, which overlies the Mancos shale.

\section{TERTIARY STRATA}

The Cretaceous and older rocks are overlain discordantly by the Tertiary formations, which aggregate several thousand feet in thickness. The lower part, usually designated the Wind River formation, consists largely of striped gray, pink, and chocolate-colored clays of Eocene age, with many beds of soft, earthy gray sandstone

\footnotetext{
"Winchester, D. E., and Woodruff, E. G., Coal flelds of the Wind River region, Fremont and Natrona counties, Wyo.: U. S. Geol. Survey Bull. 471, pp. 516-564, 1912.

${ }^{12}$ Woodruff, E. G., The Lander oil fleld, Fremont County, Wyo.: U. S. Geol. Survey Bull. 452, pp. 20-22, 1911.
} 
and at the base conglomerates of varied character. The outcrops of the formation have been eroded into badlands around the headwaters of the valleys.

At the west end of the Owl Creek Mountains and in the Absaroka Range the striped clays pass upward by insensible gradations into greenish and purplish clays which contain more or less volcanic ash and locally inclose pieces of silicified wood and plant leaves. At still higher horizons the proportion of volcanic material increases to predominance, producing tuffaceous sandstone and shale, with beds of coarse structureless agglomerate that form the rugged castellated peaks of the Absaroka Range. The age of the volcanic deposits has never been satisfactorily determined but appears to be either late Eocene or Oligocene.

Near the south end of the Wind River Range the earliest Tertiary beds exposed also consist of striped greenish and pink clays, apparently the same as the Wind River beds to the north. These clays are overlain by a varied series of grayish beds that form the greater part of the plateau in the Sweetwater region. This series includes marly limestone, greenish-gray clay, friable arkosic sandstone, and gravel, with a few chalky beds consisting in part of volcanic ash. All have been faulted and folded locally and constitute a complex series concerning which little is known. The work of Sinclair and Granger ${ }^{18}$ indicates that both the Eocene and Oligocene are represented.

\section{GLACIAI DRIFT (PLEISTOCENE)}

Most of the large canyons of the Wind River Range contained glacial tongues which left prominent moraines along the foothills. Bouldery deposits of this sort are notably prominent at the canyon mouths of North and South forks of Little Wind River and North and Middle forks of Popo Agie River. There are two sets of moraines of quite different ages, the earlier having been deeply intrenched before the deposition of the younger material.

\section{TERRACE GRAVEL}

Gravel-covered table-lands occur at various altitudes along the Wind River Mountains, from about that of the valley of Wind River up to more than 8,000 feet. The most conspicuous and best preserved of the high-level gravel deposits occur at altitudes of 7,200 to 7,700 feet. One of the most prominent is Table Mountain, a few miles south of Lander, which consists of a flat-topped table of beveled Chugwater red beds capped by about 200 feet of coarse, roughly stratified gravel. The slope is estimated at about 40 feet to the mile

\footnotetext{
is sinclair, W. J., and Granger, Walter, Elocene and Oligocene of the Wind River and Bighorn basins: Am. Mus. Nat. Hist. Bull., vol. 30, pp. 83-117, 1911.
} 
away from the mountain. The Tensleep sandstone ridge to the west is also beveled to a level corresponding to that of Table Mountain, as if a rather broad valley had here opened out from the range. Similar deposits of coarse gravel are found northward along the mountain front for many miles, a conspicuous example being on the north side of North Fork of Little Wind River at an altitude of 7,500 to 7,700 feet. The significance of these benches and other topographic features of the region is described by Blackwelder. ${ }^{14}$

\section{STRUCTURE}

The structure of the Wind River Range is for the most part very simple, the mountain being a broad eroded anticline whose slopes are made up of alternating hard and soft beds that have an intimate relation to the topography. Throughout most of its extent the northeast mountain slope is remarkedly free from faults, and only a few monoclinal folds vary the usual inclination of the beds toward the northeast. Parallel to the main mountain axis is a line of elongated domes extending from the upper part of the Wind River Basin southeastward past Fort Washakie and Lander and thence beyond Sweetwater River for an unknown distance. One of these domes in T. 30 N., R. $97 \mathrm{~W}$., is a prominent topographic feature known as Sheep Mountain.

The only faults of consequence in the area cut the beds of Sheep Mountain and the adjacent portion of the mountains to the southwest. There has been a small amount of overthrust faulting parallel to the axis of the Sheep Mountain anticline, but by far the most pronounced fault line in the area extends at right angles to the axis, apparently being continuous with the fault in the southern part of T. 30 N., R. 98 W., which has produced an offset of the beds on the south side of about 3 miles to the east. From Sheep Mountain this fault line is marked by a prominent escarpment extending northeastward for about 4 miles, to the region where the Tertiary tablelands cover the older strata.

\section{TOWNSHIP DESCRIPTIONS}

On the northeast slope of the Wind River Range phosphate occurs in the Phosphoria formation at two principal horizons-one a little above the middle and the other 40 to 50 feet above the base. Their stratigraphic positions are shown in the section measured on South Fork of Little Wind River, which is given in detail on pages 11-12. The character of the phosphate beds as found in outcrops along the mountain front in each township is described below, the discussion beginning with the township on the northwest opposite Fort

14 Blackwelder, Eliot, Post-Cretaceous history of the mountains of central Wyoming: Jour. Geology, vol. 23, pp. 97-117, 193-217, 307-340, 1915. 
Washakie. Sections of the beds at each sampling point are shown on the map (Pl. III).

\section{T. 1 N., R. 3 W.}

T. 1 N., R. 3 W. Wind River meridian, is within the Shoshone Indian Reservation, about 8 miles west of Fort Washakie. Topo. graphically the area is about equally divided between the rugged foothills on the southwest and the relatively flat edge of Wind River Basin on the northeast. The principal drainage line is North Fork of Little Wind River, which rises in the high mountains to the west. The rugged western portion of the township has not been subdivided into sections.

There are two small ranches among the red hills, along the mountain base. One of these, on South Fork of Sage Creek, obtains water for irrigation from that stream. The other, which occupies parts of secs. 10 and 11, utilizes water that is diverted from St. Lawrence Creek, a branch of North Fork of Little Wind River.

The outcrop of the Phosphoria beds extends diagonally across the central part of the township and dips $15^{\circ}-40^{\circ} \mathrm{NE}$. In the belt of Tensleep sandstone and underlying formations closely paralleling the Phosphoria on the southwest the beds are more steeply tilted, the dip being $50^{\circ}$ to $70^{\circ}$; in the Chugwater red beds on the northeast the dip flattens to a maximum of about $15^{\circ}$. The valley of North Fork of Little Wind River and the adjacent hills are littered with glacial drift, which covers the bedrock, producing an extremely bouldery surface that is unsuited for agriculture. On the north side of the valley and about 1,200 feet higher is a gravel-covered mesa 3 miles long whose surface slopes gently basinward. Its altitude' ranges from about 7,500 to 7,700 feet.

In this township the Phosphoria formation has a thickness of about 290 feet and contains the two usual phosphate beds, one 55 feet and the other 200 feet above the Tensleep sandstone. The lower bed was not seen in the township, and its presence is inferred from the fact that it is present in fair development on South Fork of Little Wind River a few miles to the south.

The upper bed was sampled at two localities, in the SW. 1/4 sec. 4 and the NW. $1 / 4$ sec. 21. At both places it is a dark-brown oolitic sandy rock, containing fossils. In sec. 4 the thickness is $21 / 2$ feet and the tricalcium phosphate content averages 41.2 per cent. In sec. 21 the thickness is 2 feet and the tricalcium phosphate content 46.1 per cent. The bed is overlain by 10 feet or so of fissile shale, dark in the lower portion and gray above, with one or more thin layers of oolitic phosphate toward the top. Beneath the principal bed is fossiliferous gray limestone. 


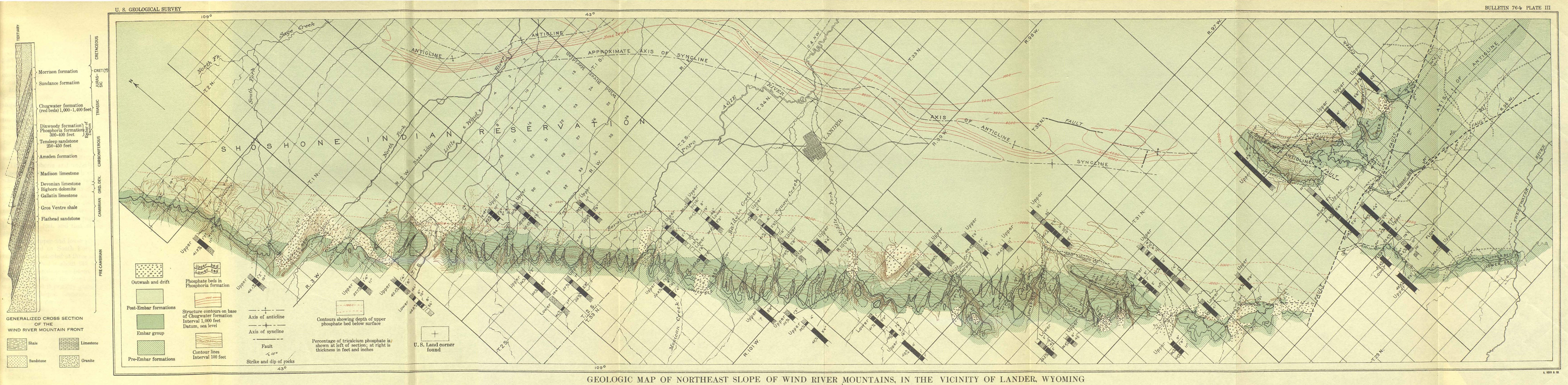





\section{T. 1 S., RS. 2 AND 3 W.}

All of T. 1 S., R. $3 \mathrm{~W}$., is mountainous, and only the northeastern part has been subdivided into sections. The Phosphoria formation is present only in secs. 1, 2,12, and 13, and the outcrop is in large part covered by glacial drift. Few exposures of the phosphate beds were found.

In the adjoining township on the east (T. 1 S., R. 2 W.) the Phosphoria crops out in a broad belt 1 to 2 miles wide with dip slopes inclined northeastward at angles of $10^{\circ}$ to $15^{\circ}$. South Fork of Little Wind River, a large stream, flows eastward through the township in an irregular course. The valley floor is greatly littered with glacial drift, which spreads in a fanlike bouldery deposit over the low country at the canyon mouth, rendering a large area unfit for cultivation. Glacial drift also covers parts of secs. 5, 6, 7, and 8. The two branches of Trout Creek are bordered by arable land, some of which is under cultivation.

The Phosphoria and underlying formations are remarkably well exposed in the canyon walls of South Fork of Little Wind River, where the rocky valley has been scraped bare and furrowed by the grinding action of the valley glacier. In fact, the scouring action in the upper canyon has left bare rock which furnishes but little opportunity for the forest to obtain a foothold. A detailed measurement of the Phosphoria strata as found on the north side of the valley in sec. 17 is given on pages 11-12. The thickness at that noint is about 285 feet, and that of the underlying Tensleep sandstone 480 feet.

Both the upper and lower phosphate beds are recorded in the section measured on South Fork of Little Wind River. The upper bed was also sampled at three additional localities in secs. 21 and 35 .

The lower bed is about 145 feet below the upper one and 54 feet above the Tensleep sandstone. It consists of dark-gray granular rock with shells of the fossil Lingulidiscina and greenish specks of a mineral that is possibly glauconite. The bed, including a 10-inch layer of dark-gray limestone, has a thickness of 3 feet, and the lower richest portion, 20 inches thick, averages 44.8 per cent of tricalcium phosphate. It is evident that this bed varies greatly in thickness from place to place, for in sec. 2 of the adjoining township to the south it is only 7 inches thick.

The upper phosphate bed ranges from 27 to 34 inches in thickness and contains from 30.3 to 42.5 per cent of tricalcium phosphate; it is leanest in the southeastern part of the township. A sample from a layer 17 inches thick, representing the richest portion of a 33-inch bed in sec. 21, gave on analysis 51.7 per cent of tricalcium phosphate. The upper bed is underlain by the usual gray fossiliferous limestone, which is also leanly phosphatic. 


\section{T. 2 S., RS. 1. AND 2 W.}

The Phosphoria beds extend diagonally across the northeast corner of T. 2 S., R. 2 W., and the southwest corner of T. 2 S., R. 1 W., forming a belt about 1 mile wide. They dip $12^{\circ}-15^{\circ} \mathrm{NE}$. The dip slope formed by the upper bryozoan-bearing limestone is deeply notched at intervals of about half a mile by sharp ravines occupied by small intermittent streams of water, which unite to form Mill Creek and Soral Creek. Along the mountain base are numerous springs, which to a large extent supply what little water appears in those streams.

Practically all of T. 2 S., R. 2 W., is mountainous and suitable only for grazing. Much of T. 2 S., R. $1 \mathrm{~W}$., is only moderately rough, and along and near North Fork of Popo Agie River there are large tracts of irrigable land. Parts of secs. 20 and 21 are covered with glacial drift that is too rocky for cultivation.

The following stratigraphic section, measured by A. R. Schultz, represents the Phosphoria and Dinwoody formations as found on South Fork of Trout Creek in sec. 2, T. 2 S., R. 2 W. It is noteworthy that the lower phosphate bed, which in the township to the north is 3 feet thick, is only 7 inches thick here. It resembles the bed as found elsewhere, however, in that it contains an abundance of Lingulidiscina.

Geoloyic section in sec. 2, T. 2 S., R. 2 W.

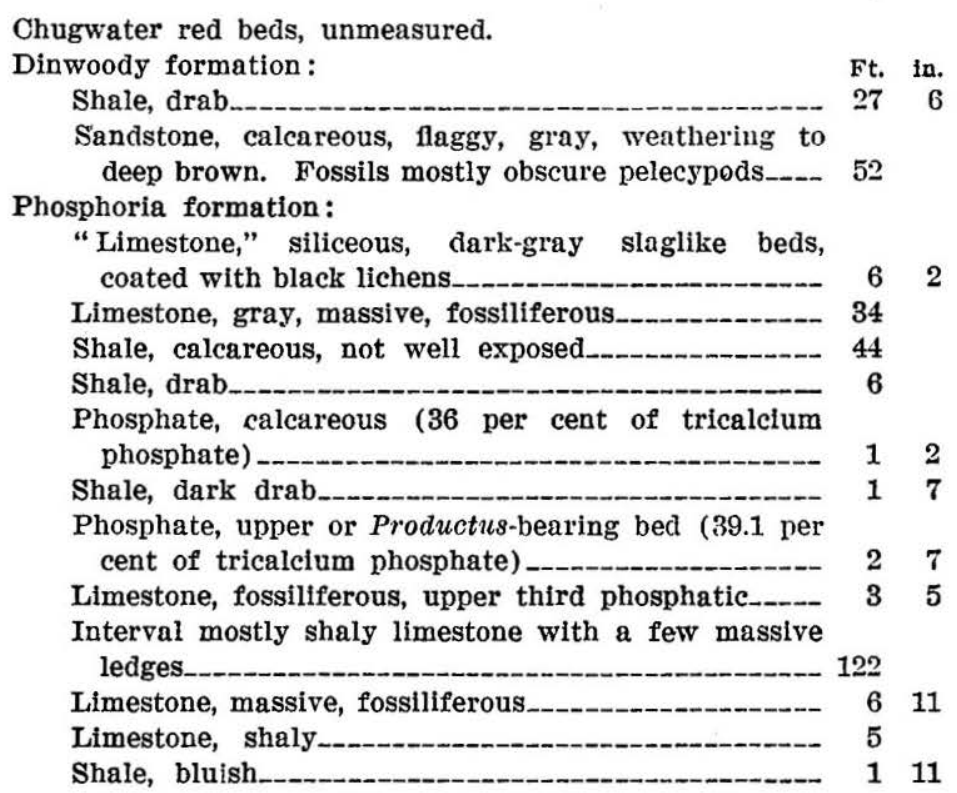


Phosphoria formation-Continued.

Ft. in.

Phosphate, lower or Lingulidiscina-bearing bed (46.2

per cent of tricalcium phosphate)

Shale-_-_-_- 4

Limestone, fossiliferous, phosphatic______________ $\quad 14$

Limestone, mostly covered to top of Tensleep sand-

The upper phosphate bed consists of two parts-a lower one 31 to 34 inches thick separated from an upper thinner layer by 15 to 19 inches of shale. In the exposures along North Fork of Popo Agie River sampled by Blackwelder the dividing shale band appears to be lacking and there is a solid bed of phosphate $41 / 2$ feet thick, containing 42.4 per cent of tricalcium phosphate. The phosphate bed is therefore more valuable at this point than anywhere to the northwest in the Wind River Range. Sections of the beds where sampled in T. 2 S., Rs. 1 and 2 W., are shown on the map (Pl. III).

\section{T. 33 N., R. 101 W.}

All but about 3 square miles in the northeastern part of T. 33 N., R. $101 \mathrm{~W}$. sixth principal meridian, is mountainous. Limestone beds of the Phosphoria formation outcropping in a belt 1 to 2 miles wide and dipping $10^{\circ}-13^{\circ} \mathrm{NE}$. produce the usual faceted dip slopes along the mountain front. Glacial drift covers a small area within and along the border of North Fork of Popo Agie River, and an outwash deposit of terrace gravel at an altitude of about 7,200 feet covers parts of secs. 13, 14, and 23. Mexican Creek and Baldwin Creek, both fair-sized permanent streams, oecupy sharp V-shaped canyons, in the walls of which are excellent exposures of the rocks.

Complete exposures of the upper and lower phosphate beds were found along an irrigation ditch on the south side of North Fork of Popo Agie River in sec. 2, about 250 feet above the valley. The ditch extends southeastward along the base of the mountain, and where it crosses Mexican Creek the upper phosphate bed is again perfectly exposed.

The upper bed on the south side of Popo Agie Valley, as shown in the section on the map (PI. III), consists of 41 inches of dark granular phosphate rock, fossiliferous in the lower part and averaging 40.6 per cent of tricalcium phosphate. Above this bed is 12 inches of clay shale, overlain by another layer of phosphate rock $81 / 2$ inches thick. The changeable character of the bed is illustrated by the fact that where sampled by Blackwelder half a mile to the north, across the valley, it is 54 inches thick and yields on analysis 42.4 per cent of tricalcium phosphate. On Mexican Creek the upper bed is 57 inches thick and contains a thin layer of limestone in the upper part but no shale. The analyses of the sereral parts of this bed 
give an average yield of 34.8 per cent of tricalcium phosphate. The following section illustrates the sequence of strata associated with the upper phosphate bed on Mexican Creek:

\section{Section measured on Mexican Creek}

Dinwoody formation:

Limestone, sandy, thin bedded.

Ft. in. 30

Phosphorla formation:

Limestone, dolomitic, thin bedded, weathering to slaglike siliceous slabs covered with black lichens.

Limestone, even bedded; white; contains Derbya and Leioclema

Chert, nodular, in shaly matrix grading upward into cherty gray glauconitic limestone; Bryozoa plentiful

Shale, dark, calcareous, with lenses of limestone in upper portion.

Phosphate, with shaly laminae (30.4 per cent of tricalcium phosphate) -

Limestone, phosphatic (8.7 per cent of tricalcium phosphate)

\begin{tabular}{ccc} 
& 8 & \\
& 45 & \\
& 1 & $21 / 2$ \\
8 & & 4 \\
& 1 & $101 / 2$ \\
\hline$a$ & & \\
\hline 8 & 1 & 4
\end{tabular}

The lower phosphate bed was seen at one point in the township along the irrigation ditch in sec. 2. It lies approximately 145 feet below the upper bed and is 18 inches thick. A sample yielded on analysis 52.6 per cent of tricalcium phosphate.

\section{T. 33 N., R. 100 w.}

The dip slopes of Phosphoria limestone extend across the southwest corner of T. 33 N., R. 100 W. To the east are numerous hogback ridges of the Chugwater and higher strata. In sec. $T$ is an isolated hill about $\tau, 000$ feet in altitude, capped by coarse gravel. It lies opposite a deposit of gravel at a corresponding altitude in sec. 14 of the adjoining township to the west. Much of this township is capable of cultivation and has been brought under irrigation with water from North and Middle forks of Popo Agie River and Baldwin and Squaw creeks, which flow through the central portion.

In the numerous sharp ravines along the mountain front are good exposures of the Phosphoria formation and its two phosphate beds. The lower bed, which is a little less than 3 feet thick, is the more valuable, containing nearly 60 per cent of tricalcium phosphate; 
the upper bed, though slightly more than 3 feet thick, contains at best only 41 per cent of tricalcium phosphate. The results of measurement and sampling of the upper bed on Baldwin Creek and Squaw Creek are shown on the map. A complete section of the Dinwoody and Phosphoria beds as found on Baldwin Creek is given below.

Section on Balduoin Creek in the SW. 1/4 sec. 18, T. 33 N., R. 100.W.

Dinwoody formation:

Limestone and calcareous shale, laminated, weathered

deep brown; upper portion increasingly shaly...---.

Phosphoria formation:

Limestone, gray to drab; lower part massire; upper portion weathers like slaking lime; fossils plentiful in lower part.

Limestone, bluish drab to gray; weathered rocks resemble pebble-dash surface; somewhat cherty

Phosphate, oolitic (18.5 per cent of tricalcium phosphate)

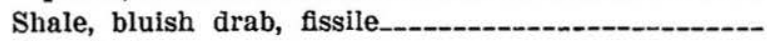

Phosphate.

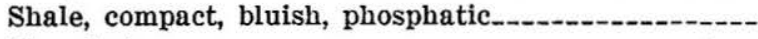

Phosphate.

(Sample of above three beds gives 41.1 per cent of tricalcium phosphate.)

Limestone, gray, shaly, forming prominent ledge beneath phosphate; lower part of interval not well exposed

Phosphate, Lingulidiscina horizon, glauconitic (57.9 per cent of tricalcium phosphate)

Limestone and covered

Tensleep sandstone, unmeasured.
Ft. in.

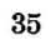

\section{T. 32 N., R. 100 W.}

The southwest half of T. 32 N., R. 100 W., is a part of the Wind River Mountain slope, the lower portion of which is faced with the upper bryozoan-bearing limestone of the Phosphoria formation, dipping $8^{\circ}-12^{\circ} \mathrm{NE}$. Table Mountain, a prominent topographic feature set out from the main mountain front, is a flat-topped gravelcovered mesa 7,100 to 7,200 feet in altitude, covering about 3 square miles. The gravel cap, which is made up of very coarse, rudely stratified material, has a thickness of about 200 feet and rests upon beveled Mesozoic beds. Opposite Table Mountain is a corresponding nearly level plain extending far into the mountains. It is one of the ancient outwash channels whose deposits occur at so many places along the mountain front at altitudes of 7,200 to 7,700 feet. Gravels of this erosional stage also occupy parts of secs. 34 and 35 .

Agricultural activities in this township are confined chiefly to the valley floor of Middle Fork of Popo Agie River, which, although 
partly littered with bouldery glacial drift, has many prosperous ranches. Small areas are also under cultivation along and near Willow Creek, in the southeastern part of the township.

Exposures of the Phosphoria formation may be seen in almost all of the sharp ravines or canyon walls formed by the resistant limestone members. The phosphate rock where not completely exposed can readily be uncovered at favorable places. The following section, measured on a branch of Willow Creek in the SW. 1/4 sec. 25, shows nearly all of the Phosphoria formation.

Section of Phosphoria formation on North Fork of Willon Creek

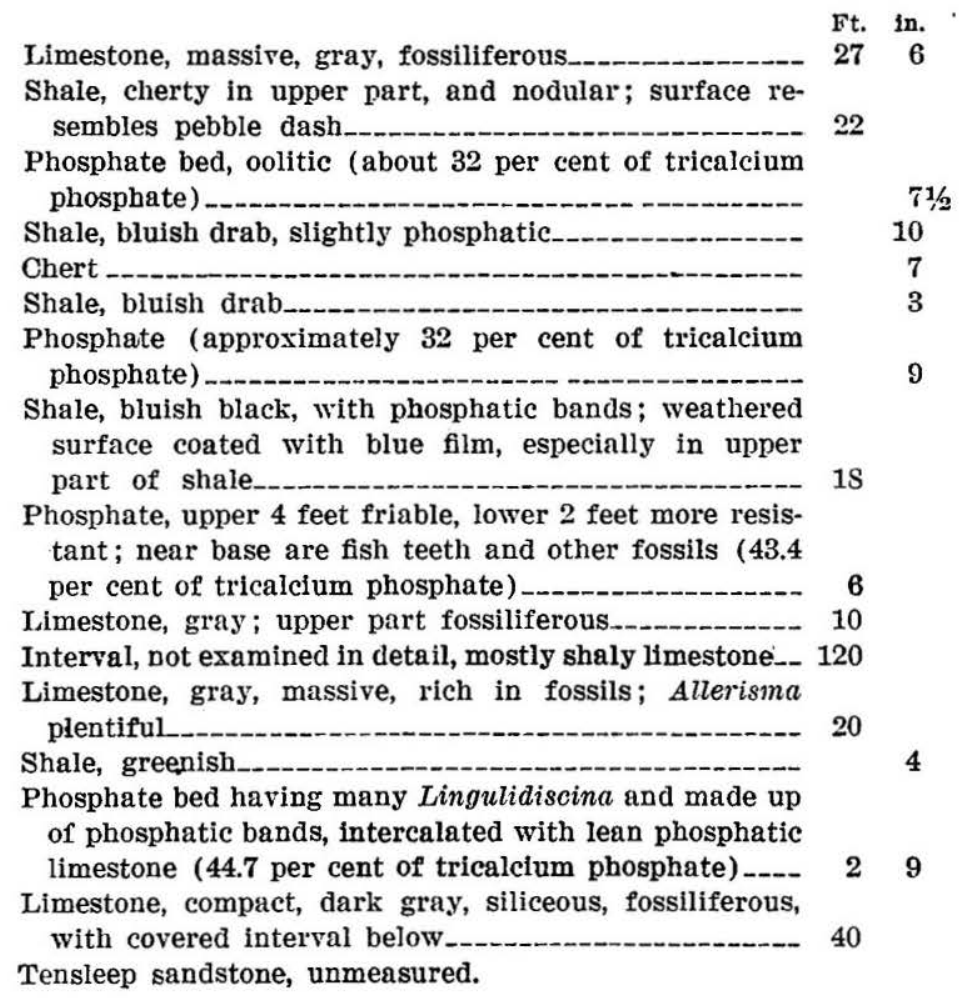

The upper bed was measured and sampled at four localities in. the township. It ranges from $31 / 2$ to 6 feet in thickness and is: thickest in the southeastern part of the township, in sec. 25 , where it is also the richest, carrying $49.2 \mathrm{per}$ cent of tricalcium phosphate compared with only 43.2 per cent in sec. 5. The exposures in sec. 25 . probably represent the upper bed at its best in the Wind River Mountains.

The lower bed is of less prospective value than the upper, being only 12 to 33 inches thick and not especially rich when the entire bed is included in the sample. The upper portion, 12 to 18 inches. 
thick, is generally the richest in tricalcium phosphate, containing between 50 and 60 per cent. Beneath it is lean phosphatic limestone with thin richer layers made up largely of the phosphatized shells of Lingulidiscina. The lower bed was sampled at two points, and the results are shown on Plate III.

\section{T. 31 N., R. 99 W.}

The surface of T. 31 N., R. 99 W., has a relief of more than 2,500 feet. The southwestern part constitutes the mountain slope of the Wind River Range, at the base of which is an anticlinal ridge about 1,300 feet higher than the adjacent valley. East of Red Canyon Creek the red beds form a broken belt of country about a mile wide, beyond which are succeeding hogback ridges of higher rocks interspersed with shallow valleys. There is little wood in this part except a scrubby species of juniper that favors the most rocky slopes. In the southwestern part of the township there is a small amount of pine timber along the principal ravines.

The township is about 10 miles south of Lander, and a daily stage to Atlantic follows a route southeastward across it along the valley of Red Canyon Creek. In this valley are several ranches where alfalfa hay is the principal crop. Young's ranch, at the mouth of the canyon of South Fork of Popo Agie River, has been occupied for over 40 years, and the owner has one of the largest and most successful apple orchards in the State.

The general dip of the beds along the main mountain slope is $5^{\circ}-25^{\circ} \mathrm{NE}$., there being several terrace-like undulations. In the central part of the township is a sharp anticline which pitches northwestward and stops abruptly at its south end, near Deep Creek. The west flank is inclined at angles of $45^{\circ}$ to $50^{\circ}$; the east flank at angles of $10^{\circ}$ to $20^{\circ}$. At the south end of the anticline along Deep Creek there is a thrust fault having a displacement of about 30 feet.

In the NW. $1 / 4$ sec. 8 and adjacent territory minor structural disturbances appear to have involved chiefly the Phosphoria beds, leaving the underlying rigid Tensleep sandstone practically unaffected as seen along the canyon walls. The disturbances were apparently in the form of bed thrusting and folding, there being local monoclinal undulations where the dip increases from $13^{\circ}$, the usual angle, to about $25^{\circ}$. The strike varies greatly from place to place. The resultant topography resembles that of a large landslide surface.

The strata exposed in the township include formations ranging from the Madison limestone to the Mancos shale. The Dakota sandstone and associated rocks, lying a few hundred feet above the top of the Chugwater red beds, form a hogback ridge that extends across the northeast corner of the township. Beneath these beds are the weak Morrison and Sundance formations, which are represented by 
a broad, open valley. The Chugwater formation is about 1,400 feet thick and has in its upper portion a massive sandstone member that forms a high ridge east of Red Canyon. The lower Chugwater beds, of brick-red color, appear in the prominent escarpment on the north side of the valley. The Dinwoody formation, underlying the Chugwater, is only 30 feet thick and consists of weak clay shale and brown flaggy limestone, with more resistant limestone beds at the base. The Phosphoria formation has the usual upper resistant limestone member that controls the long dip slopes which are so prominent along the mountain. The formation is 265 feet thick and rests on the Tensleep sandstone, which is about 400 feet thick.

The Phosphoria formation as seen along South Fork of Popo Agie River is illustrated by Plate II; $A$ shows the upper bryozoan-bearing limestone, about 33 feet thick, which controls the dip-slope topography and also the positions of the two phosphate beds, and $B$, which is a close view, shows the nodular chert underlying the upper bryozoan-bearing limestone. The lower part of this chert is shaly and has numerous phosphate bands from a fraction of an inch to 5 inches in thickness. The cherty beds rest on brownish-black shale about 38 feet thick, which has thin phosphate bands in the lower portion. The upper phosphate bed, about 8 feet thick, lies at the base of the shale member. The beds in the middle of the Phosphoria formation are not well exposed, for, being less resistant, they form a sloping profile covered mostly by talus which supports a growth of juniper bushes. At 40 feet above the base of the formation is the lower phosphate bed, $21 / 2$ feet thick. It is overlain by 25 feet of white chalky limestone rich in fossils and underlain by siliceous dark-gray compact limestone having few fossils.

The first discovery of phosphate rock in the Lander district was made at Young's ranch in 1909, by E. G. Woodruff, who without suspecting its phosphatic character recognized the rock as the same as the "oil sand" in the Dallas oil field. It is of interest to note that this discovery was made in the region where the phosphate beds are most valuable, for they are at their best in this township and the adjoining ones to the north and south.

The upper bed ranges from 3 to 7 feet in thickness and as usual contains shaly calcareous layers low in phosphate, interbedded with richly phosphatic layers. Some of the individual laminae contain nearly 60 per cent of tricalcium phosphate, but when the percentage in these is averaged with that of the lean laminae the content of the bed as a whole is 35 to 40 per cent, a low grade as compared with that of the lower bed. The dark granular rock from the upper bed when freshly broken gives a noticeable oily odor.

'At the sampling point in sec. 8, near Young's ranch, the upper bed has a thickness of 86 inches and averages 35.5 per cent of 
tricalcium phosphate. In sec. 33 the thickness is about 3 feet and the tricalcium phosphate content 36.8 per cent. Above the principal bed are three or more thin bands of phosphate rock distributed through the dark-brown shale.

The lower phosphate bed has been uncovered in sec. 8 in a prospect pit dug in the search for gilsonite. The rock is nearly black and contains calcite vugs lined with more or less black bituminous material. Fossils are abundant throughout the bed. In addition to the everpresent disk-shaped shells of Lingulidiscina they include abundant small pelecypods of the genus Nucula. The lower bed, like the upper, contains thin laminae of shale and limestone that considerably reduce the tricalcium phosphate average when included in the sample. The results of analysis of a gross sample from a $21 / 2$-foot bed in Little Popo Agie Canyon give 53.2 per cent, and of a sample from a 4-foot bed on Deep Creek in sec. 26, 52.2 per cent. Samples from select laminae would doubtless yield considerably more than 60 per cent. Sections of the bed are given on the map (Pl. III) and also in detail below.

Section of lover phosphate bed on Little Popo Agie River

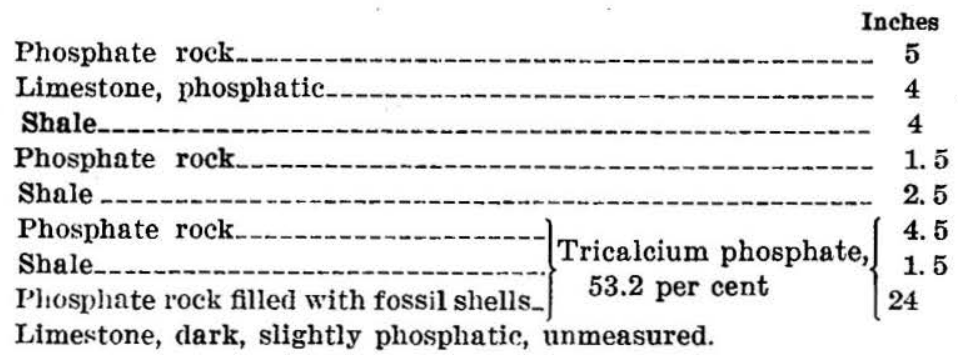

Section of luncr phosphute bed on llecp Creel in the SW. 1/4 sec. 26, T. 81 N., R. $99 \mathrm{~W}$.

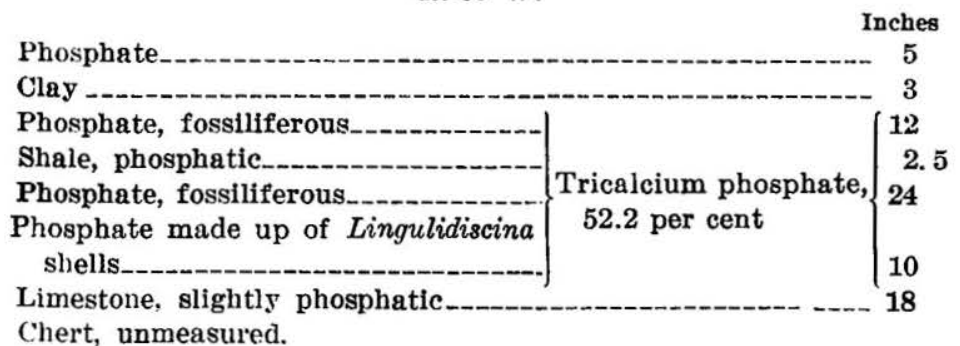

T. 30 N., R. 99 w.

T. 30 X., R. 99 W. sixth principal meridian, lies about 18 miles south of Lander. The Lander-Pinedale stage route crosses southwestward through its central portion. Although the southwestern two-thirds of the township is a part of the Wind River Mountains, $5525-24-3$ 
the relief is not great, and the surface is only moderately rugged. Timber is not nearly so plentiful as in the townships to the northwest, and the scattered woodlands include many thickets of quaking aspen.

Over most of the northeastern part of the township is a tableland approximately 7,000 feet in altitude, covered with Quaternary gravel, locally underlain by clays and arkose sands which rest upon the beveled edges of the old rock formations. The gravel consists in large part of materials derived from crystalline-rock outcrops in the mountains to the south, there being an abundance of magnetite schist pebbles which deflect the needle to so great an extent that compass surveys are impracticable.

Twin Creek, Usher Creek, and Stanbaugh Creek are all small streams with narrow valleys. At a few places their valley bottoms widen sufficiently to attract the settler, but the altitude is so great that about the only successful crop is hay. Ranching is carried on in a small way in secs. 1,2 , and 12 , and other areas would probably be utilized were there a larger water supply for irrigation.

The structure of the portion of the township included in this report shows no irregularity, the beds being inclined northeastward at angles of $8^{\circ}$ to $12^{\circ}$. The Tensleep, Phosphoria, Dinwoody, and Chugwater formations are covered throughout considerable areas by the outwash gravels already mentioned, which probably correspond in age with the deposits on Table Mountain. The gravels are more or less auriferous, and in past years several projects to work them for gold have been promoted.

The Phosphoria beds are well exposed along Twin Creek at the east side of sec. 11, where the following section was measured. The exposures also include beds consisting of soft greenish-gray shales about 35 feet thick representing the entire Dinwoody formation.

Section of Phosphoria formation on T'win Creck in secs. 11 and 19, T. $30 \mathrm{~N}$., R. $99 \mathrm{~W}$.

\begin{tabular}{|c|c|c|}
\hline & Bt. & in. \\
\hline 9 & & \\
\hline $\begin{array}{l}\text { hert, upper part nodules embedded in limestone, lower } \\
\text { part nodules in greenish shaly matrix }\end{array}$ & 16 & \\
\hline hale, greenish drab, containing green nodular concretions- & 1 & \\
\hline aale, dark drab & & 10 \\
\hline hosphate, impure (21.5 per cent of tricalcium phosphate) & & 4 \\
\hline hale, drab & 22 & \\
\hline hosphate (33.8 per cent of tricalcium phosphate) & & 6 \\
\hline Shale, dark drab, fissile & 7 & 6 \\
\hline $\begin{array}{l}\text { Phosphate, friable, calcareous, dark ( } 37.2 \text { per cent of tri- } \\
\text { calcium phosphate) }\end{array}$ & 4 & \\
\hline Phosphate, dark gray & 1 & \\
\hline hosphate & & \\
\hline
\end{tabular}




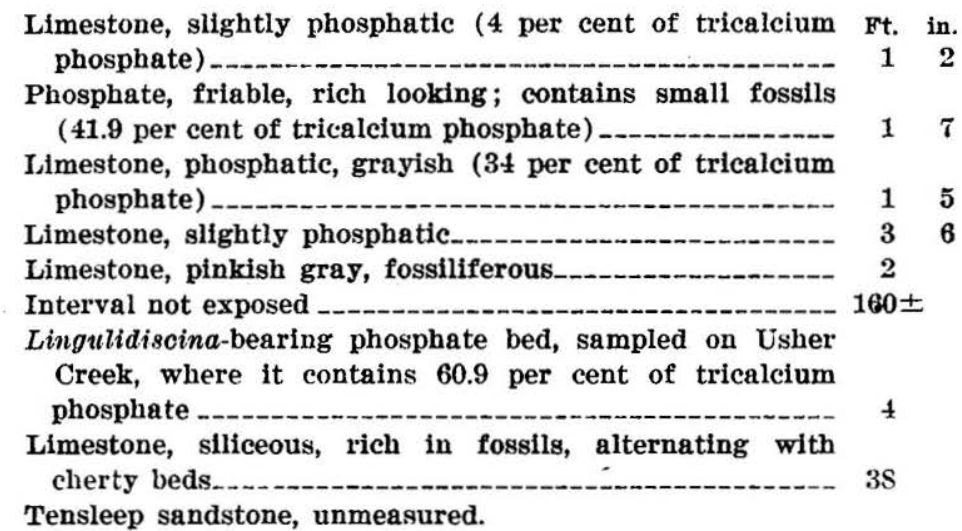

The upper phosphate bed consists of a number of more or less calcareous laminae, none of which were found to contain more than 43 per cent of tricalcium phosphate. A gross sample representing 5 feet of the richest portion gives about 37 per cent.

Exposures of the lower bed were found only on Usher Creek near the north edge of sec. 24 . It is a single rich-looking dark-gray layer 4 feet thick, yielding on analysis 60.9 per cent of tricalcium phosphate. Float fragments of the bed are easily discovered along the outcrop, for the reason that the weathered rock assumes a bluishgray skimmed-milk color. The flat shells of the fossil Lingulidiscina, the size of a 5-cent coin, are always to be seen in it.

\section{T. 30 N., R. 98 W.}

The surface of T. 30 N., R. 98 W., is in part made up of low hogback hills in Mesozoic strata, with extensive gravel and sand covered table-lands in the southwestern portion above which the older tilted strata project here and there. The general altitude of the table-lands is about 7,000 feet, and that of the lowest valleys in the northeastern part of the township is about 6.300 feet. The area is used solely for sheep grazing.

There is but little opportunity to observe the details of structure and stratigraphy in the southwestern part of the township, for the reason that the rocks are concealed by an extensive blanket of Tertiary clays and arkosic sands. Over these grayish to white beds is a thin veneer of gravel, made up in large part of pebbles of hornblende and magnetite schist. It is certain, however, that a fault of large displacement extends across the southern part of the township with a trend of about N. $20^{\circ} \mathrm{E}$., almost at right angles to the strike of the nearest hogback exposures of the Phosphoria and Tensleep beds. On the south side of the fault, 3 miles to the east 
of the beds on the north side, is an isolated low ridge of Tensleep sandstone that strikes about N. $50^{\circ} \mathrm{W}$. and dips $22^{\circ} \mathrm{NE}$. This may be assumed to denote a stratigraphic displacement of more than 1 mile of the strata on opposite sides of the fault. There is, however, another possible interpretation. Along Stanbaugh Creek in sec. 20 is a well-defined anticline trending southeastward and extending under the cover of Tertiary beds in sec. 28. It is barely possible that this fold, although narrow and insignificant in sec. 20, broadens toward the southeast, and that its axis changes to a more easterly direction. The upper phosphate bed as projected under the Tertiary covering might under this interpretation be supposed to extend in an easterly direction to the fault at a point approximately 1 mile west of the same bed on the other side of the fault, instead of nearly 3 miles, as indicated on the map.

In the description of T. 30 N., R. 99 W., adjoining this one on the west; is given a measurement of the Phosphoria beds which may also be regarded as representative of this area.

Fair but incomplete exposures of the Phosphoria beds may be seen along Stanbaugh Creek in secs. 19, 20, and 30, but they are not so good as those in sec. 1, which are described below under the heading "Sheep Mountain anticline."

Natural exposures of the phosphate beds are few in this township, and at only one point was an outcrop of the upper bed suitable for sampling found. The lower bed is even less satisfactorily exposed and was not sampled within the township. The positions of both the upper and lower beds are readily discovered by means of the phosphate float, which appears as diark-brown granular rock with the typical bluish-gray "bloom" on weathered surfaces.

The upper phosphate bed was sampled on the banks of Stanbaugh Creek in sec. 20, where it was found to be 44 inches thick and to contain 45 per cent of tricalcium phosphate. The lower bed where sampled on Usher Creek in sec. 24 of the adjoining township to the west is 48 inches thick and contains 60.9 per cent of tricalcium phosphate.

Evidently it thins northeastward under cover, for it is missing along the slopes of Shot Mountain, in the northeastern part of the township.

SHEEP MOUNTAIN ANTICLINE, T. 30 N., R. 97 W., AND T. 31 N., RS. 97 AND $98 \mathrm{w}$.

SURFAOE FEATURES

Sheep Mountain is a conspicuous topographic feature resulting from the erosion of hard Paleozoic rocks which have been folded into an anticline. The highest portion of the mountain is formed by sandstone beds of the Tensleep formation, which in the northwest- 
ern part of T. 30 N., R. 97 W., have an altitude of a little more than 7,500 feet. The central axis of the mountain trends roughly southeast, swinging to east in the eastern part of the township. The strata dip away from this central axis, and the mountain is encircled by successively lower hogback ridges of the red beds and overlying formations, - which are separated from harder rocks forming the central mountain mass by a strike valley. In the central part of $\mathrm{T}$. 30 N., R. $97 \mathrm{~W}$., is a low gap that extends northeastward across the mountain and is used by sheepmen who have made wagon trails that give access to various parts of the bench lands e'ast of Sheep Mountain. There are a number of ranches close to the base of the mountain-two at the upper and lower ends of Beaver Creek canyon, several along Twin Creek on the southwest side, and another at the northwest end, where there are large springs.

Beaver Creek, the principal stream within the area, has not a perennial flow throughout its course, being fed chiefly by local springs except early in the summer, when the melting of the snows in the mountains to the southwest brings a large flow. The stream has cut a deeply notched canyon across Sheep Mountain in a fairly direct course, regardless of the hardness of the strata. The extension of a drainage channel across a seemingly formidable topographic barrier is displayed on a grander scale by Wind River. which turns northward from the lowlands of Wind River Basin into a precipitous canyon with walls 2,000 feet in height cut through the Owl Creek Mountains. Drainage lines such as these may be very ancient, for their courses have evidently been maintained either since the initiation of mountain-making processes or at any rate since late Tertiary time.

\section{GEOLOGIO FEATURES}

Sheep Mountain is in alinement with the Dallas, Lander, and Fort Washakie anticlines, whose axes parallel the Wind River Range. It differs from the others, however, in being much faulted and of greater magnitude, but it displays the general habit common to all anticlinal folds in the region in that the strata on the southwest side dip much more steeply than those on the northeast side.

A fault of considerable prominence extends a little north of east across Sheep Mountain and appears to coincide with a fault of large displacement that occurs along the Wind River Mountain front about 4 miles to the southwest. The displacement, for the most part vertical, with the north side depressed, may be as much as 4,000 feet. From the vicinity of Beaver Creek, in sec. 22 , T. 30 N., R. 97 W., the eastward extension of the fault plane is conspicuously indicated for several miles by a wall of Madison limestone dragged into a vertical position and adjoined on the south by Cambrian and pre-Cambrian rocks. 
North of the principal fault in Sheep Mountain and at about right angles to it are two overthrust faults with the displacement toward the northeast. One, extending along the crest of the mountain, has carried the Tensleep sandstone over the Phosphoria beds. The other, on the northeast slope, has had a similar effect and in addition has carried a block of Phosphoria beds over Chugwater strata. Another fault of considerable prominence has modified the structure of the anticline in its southern portion, beds well up in the Cretaceous along the mountain base being in contact with Cambrian shales east of Beaver Creek in secs. 35 and 36, T. 30 N., R. 97 W. The fault plane trends nearly due east, and its extension in both directions is concealed by a cover of Tertiary deposits.

Rocks of the entire Paleozoic sequence are exposed along Beaver Creek canyon in sec. 26, T. 30 N., R. 97 W. The structure is somewhat complicated by minor faults, but the exposures are favorable for detailed stratigraphic study. The crystalline rocks appear at ihe north edge of sec. 26 on the east bank of Beaver Creek, and the outcrop widens eastward from this vertex and occupies a large area in the adjoining township to the east. The rock is granitic in composition and has a slightly gneissoid texture. The identity of the limestone series is not certain, but it seems probable that the ferruginous shales and thin-bedded limestones of the Cambrian are directly overlain by the Madison limestone, which is considerably reduced in thickness from its maximum in the Wind River Range. The Tensleep sandstones show the usual massive, cross-bedded character, are ripple marked on the bedding planes, and locally contain indistinct impressions of plants. Their thickness is about 300 feet.

The Phosphoria formation was measured on Beaver Creek in sec. 10. T. 30 N., R. 97 W., and the thickness was found to be 283 feet. The following details were recorded at that point:

\section{Section of Phosphoria and Dinurood!/ formations on Bcaver Creek}

Chugwater formation:

Red sandy shales, unmeasured.

Dinwoody formation:

Lower portion thin-bedded drab shales; upper 6 feet gray flaggy sandstone, weathering brownish

Phosphoria formation:

Chert, gray. granular, rusty-appearing rock which resembles fine-grained quartzite. It has been mistaken for a quartz ledge and prospected for gold in places. Under cover this rock is mostly sillceous limestone

Clay, yellowish, marly, with chert nodules and geodes of quartz and calcite-_._-

Limestone, brownish gray, with calcite geodes_._._...- 6

Chert nodules in a matrix of greenish sandy shale..... 17 
Phosphoria formation-Continued.

Ft. In.

23

Shale, black to drab; weathers to talus slopes

Produotus-bearing phosphate bed:

Phosphate, grayish, pebbly, argillaceous, containing Productus nevadensis (29.3 per cent tricalcium phosphate)

Phosphate, impure, calcareous

Shale, calcareous, phosphatic

Limestone, phosphatic, a mass of fossils, chiefly Productus

Limestone, massive, brownish gray, filled with fossils, slightly phosphatic.

Shales and limestone; drab-gray shales, sandstone, chert beds, and intercalated limestones, few of which are well exposed.

Tensleep sandstone, base not exposed.

The upper or Productus-bearing phosphate bed is the only one found in the Phosphoria formation in Sheep Mountain, the lower bed being so insignificant that even its position can be found only with difficulty. The upper beci was measured and sampled at six points, all within T. 30 X., R. 97 W. Three of the localities are in secs. 6 and 7 , where there are almost continuous exposures; the others are in secs. 9,10 , and 12 . The bed ranges from $51 / 2$ to 11 feet in thickness and is thickest in the western part of the township. The rock is almust without exception leanly phosphatic, samples of the entire bed yielding less than 30 per cent of tricalcium phosphate and samples selected to represent the richest-looking laminae yielding at best less than 40 per cent. In appearance the rock resembles an impure argillaceous limestone, being gray in color and with a more or less oolitic texture caused by the scattered phosphate oolites.

\section{-SUMMARY OF PHOSPHATE BEDS}

On the north slope of the Wind River Mountains there are two principal phosphate beds in the Phosphoria formation, the lower one lying 40 to 55 feet above the base and the upper 60 to 75 feet below the top. The upper is the more persistent but varies considerably in thickness and percentage of tricalcium phosphate from place to place. The lower one, although rarying greatly in thickness and richness and absent in the Sheep Mountain uplift, is in its best development richer than the upper and therefore more promising as a source of phosphate rock for commercial purposes.

Lover bed.-The lower phosphate bed is at its best in T. 30 N., R. $99 \mathrm{~W}$., where, as sampled on Tisher (reek in sec. 24, it is 4 feet thick and contains 27.85 per cent of phosphorus pentoxide, equiralent to about 61 per cent of tricalcium phosphate. On Beaver Creek, 8 miles southeast of the Usher Creek locality, in sec. 5. T. $29 \mathrm{~N}$., R. 
$97 \mathrm{~W}$., the same bed is only 10 inches thick, and at a number of points farther south, on and near Sweetwater River, it is absent. The bed likewise thins eastward under cover from Usher Creek and is missing in the Sheep Mountain uplift, in Tps. 30 and 31 N., R. 97 W. It seems safe to assume that the lower bed is present and of commercial value northwestward from Usher Creek for at least 15 miles along the strike, for at the sampling points on Deep Creek, Little Popo Agie River, and Willow Creek the bed is only slightly less promising than on Usher Creek. On Deep Creek, in sec. 26, T. $31 \mathrm{~N}$., R. $99 \mathrm{~W}$., the thickness is nearly 5 feet and the tricalcium phosphate content 52.2 per cent; on Little Popo Agie River, in sec. 8 , T. 31 N., R. 99 W., the thickness is $2 \frac{1}{2}$ feet and the phosphate content 53.2 per cent; and on Willow Creek, in sec. 26 , T. 32 N., R. $100 \mathrm{~W}$., the bed is a little less than 3 feet thick and contains 44.7 per cent of tricalcium phosphate. On the Middle Fork of Popo Agie River, in sec. 8, T. 32 N., R. 100 W., the bed thins to less than 2 feet, but on Squaw Creek, in sec. 29, T. 33 N., R. 101 W., a sample was taken from a bed 32 inches thick which contained 55.9 per cent of tricalcium phosphate. The Squaw Creek locality is the most northerly point where the bed was found to be of promising thickness and richness.

Upper bed.-The upper bed differs from the lower in that it contains a large amount of sandy and clayey impurities and is generally made up of several layers of phosphate rock interbedded with shaly material. Some of the laminae a foot or so thick may be found to contain as much as 60 per cent of tricalcium phosphate, but a sample selected to represent layers having an aggregate thickness of several feet commonly shows no more than 40 per cent. The upper bed is most favorably developed from Baldwin Creek opposite Lander southeast to Usher Creek, thus agreeing in this respect with the lower bed. The following table shows the thickness and percentage of tricalcium phosphate of the upper bed at a number of localities:

Character of upper phosphate bed where most favorably developed

\begin{tabular}{|c|c|c|}
\hline Locality & $\begin{array}{c}\text { Thickness } \\
\text { (inches) }\end{array}$ & $\begin{array}{l}\text { Tricalcium } \\
\text { phosphate } \\
\text { content } \\
\text { (per cent) }\end{array}$ \\
\hline 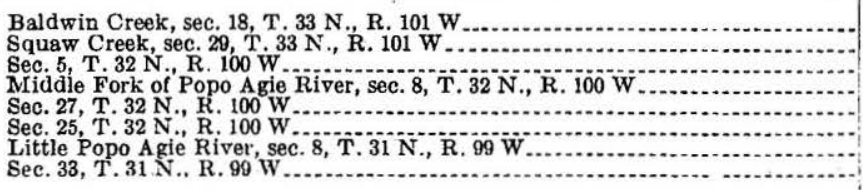 & $\begin{array}{l}27 \\
39 \\
42 \\
42 \\
72 \\
60 \\
86 \\
38\end{array}$ & $\begin{array}{l}35.3 \\
41.0 \\
43.2 \\
42.0 \\
43.4 \\
49.2 \\
35.5 \\
36.8\end{array}$ \\
\hline
\end{tabular}




\section{CHARACTER OF THE PHOSPHATE ROCK}

\section{PHYSICAL PROPERTIES}

The high-grade phosphate rock in the Wind River Mountains resembles other deposits in the Rocky Mountain region in that it is oolitic in texture, of high specific gravity, dark brown to black when freshly exposed, and bluish gray on the weathered surface. The shale, limestone, and chert that are closely associated with the upper phosphate bed are likewise so similar to those in the phosphate fields of northeastern Utah and adjacent parts of Idaho that the observer familiar with those localities would at once notice the resemblance. An important difference, however, - in the geologic sections of the two regions is that in the Wind River Range phosphate occurs at a lower horizon not known to be represented in Utah and Idaho.

The oolitic texture is most noticeable in the rock richest in phosphate, the rounded black granules giving an appearance of fish roe. In general, however, the oolites are intimately mixed with sand grains, clay, and calcareous material which forms a cementing matrix. Large fossil brachiopods of the genus Productus are plentiful in the basal portion of the upper phosphate bed at many localities. There is not everywhere a sharp demarkation between the phosphate bed and the underlying limestone, the latter commonly containing more or less oolitic granules scattered through the upper portion. The lower phosphate bed has fewer oolitic granules than the upper bed and consists in much larger part of fossils, the shells of which are phosphatized. Lingulidiscina utahensis, the most abundant fossil, has a shell of essentially phosphatic composition and appears to have furnished in large part the phosphatic material of this horizon. The shells of Nucula and other small pelecypods that are plentiful in the bed are not known to be originally richly phosphatic, but their phosphatized casts, together with a. dark amorphous rock, make up the bulk of the bed.

The specific gravity of the richer phosphate rock is noticeably greater than that of limestone and sandstone, being in certain specimens as high as 2.8. This property, together with the peculiar bluish-gray color of the weathered rock, makes it easy to recognize float particles and thus discover the outcrop.

The freshly broken phosphate rock generally has a peculiar oily odor, which is not surprising, as the same rock under cover is productive of oil in this part of Wyoming. In fact, the presence of phosphate rock in the region became known in 1909 through its content of oil. The first specimen was collected at Young's ranch, on Little Popo Agie River, by E. G. Woodruff, who was searching for an 
outcrop of the "oil sand" that was productive in the oil wells at Dallas. The specimen was shown to H. S. Gale, who at once noticed its resemblance to the Idaho phosphate rock, and on analysis in the chemical laboratory of the United States Geological Survey it was found to contain 65 per cent of tricalcium phosphate.

\section{COMPOSITION}

In the township descriptions are given the results of numerous partial analyses showing the percentage of phosphorus calculated to tricalcium phosphate. It is not unreasonable to assume that the phosphate is in this form, for the following chemical analyses show that iron and alumina are present in only small amounts. The chief impurities in the rock phosphate are sandy, clayey, more or less. calcareous sediments.

Analyses of phosphate rock from Wind River Montain

[W. O. Wheeler and Benedict Salkover, analysts]

\begin{tabular}{|c|c|c|c|c|}
\hline No. & $\mathrm{P}_{2} \mathrm{O}_{3}$ & $\begin{array}{c}\text { Equivalent } \\
\text { in trical- } \\
\text { cium phos- } \\
\text { phate } \\
\left(\mathrm{Cas}_{3}\left(\mathrm{PO}_{4}\right)_{3}\right)\end{array}$ & $\mathrm{CaO}$ & $\left.(\mathrm{Al}, \mathrm{Fe})_{2} \mathrm{O}_{3}\right)$ \\
\hdashline & & & \\
1 & 19.78 & 43.22 & 34.11 & \\
2 & 27.90 & 60.96 & 42.91 & 1.33 \\
3 & 19.87 & 43.41 & 39.01 & 2.76 \\
4 & 22.52 & 49.20 & 38.62 & 1.79 \\
5 & 24.33 & 53.16 & 40.11 & 2.04 \\
6 & 20.30 & 44.35 & 35.63 & 1.70 \\
7 & 17.01 & 37.16 & 34.76 & 1.92 \\
8 & 21.03 & 45.95 & 38.05 & 1.30 \\
9 & 20.35 & 44.46 & 38.00 & 2.66 \\
\hline
\end{tabular}

1. Upper bed, SE. $1 / 4$ sec. 18, T. 3 N., R. 4 W. Wind River meridiun.

2. Lower bed, NE. 1/4 sec. 21, T. 32 N., R. $100 \mathrm{~W}$. sixth principal meridian.

3. Upper bed, NE. $1 / 4$ sec. 27 , T. 32 N., R. 100 W.

4. Upper bed, SW. $1 / 4$ sec. 25, T. 32 N., R. 100 W.

5. Lower bed, sec. 9 , T. 31 N., R. 99 W

6. Upper bed, sec. 9 , T. 31 N., R. 99 W

7. Upper bed, SE. $1 / 4$ sec. 11 , T. 30 N. R. 99 W.

8. Upper bed, sec. 20, T. 30 N., R. $98 \mathrm{~W}$.

9. Upper bed, NE. $1 / 4$ sec. 36, T. 31 N., R. 98 W.

The phosphate rock mined for shipment in the vicinity of Bear Iake, southeastern Idaho and the adjacent portion of Utah, generally contains a little more than 70 per cent of tricalcium phosphate and less than 3 per cent of iron and alumina. It is therefore considerably richer than the rock in the Lander district, the best of which yields on analysis an amount of phosphoric acid equivalent to about 60 per cent of tricalcium phosphate.

\section{UTILIZATION AND METHODS OF TREATMENT}

Phosphate rock finds its most important use as a soil fertilizer. The finely ground rock may be used direct and also as an ingredient of artificial fertilizers. In general, however, the rock is put through 
a process of treatment which renders its phosphorus content more soluble..$^{15}$

The method of treatment generally in practice is known as the acid treatment, in which water-soluble phosphates are produced by the use of sulphuric acid. The process consists in treating the ground phosphate rock with an equal weight of acid, and the resulting product is a calcium-acid phosphate. It is said that in factory practice the product of this treatment sometimes remains moist and gummy so that it is difficult to handle and that it tends to eat the cloth bags in which it is placed for shipment. Iron and alumina are supposed to be the cause of this undesirable property in the manufactured product, as their sulphates show a tendency to take up moisture in a damp atmosphere. The combined percentage of the two radicals computed in the oxide form should, according to the manufacturers, not be more than 4 or 5 per cent. The analyses of samples from the Lander district (see p. 36) show the iron and alumina to be within the required limits.

The Lander district is rather remote from a source of supply of sulphuric acid, there being no smelters in operation in Wyoming and the nearest ones from which a supply might be derived being in Salt Lake City or Anaconda. The acid process of treatment would therefore be expensive.

A report has recently been received concerning another process of treatment practiced in Italy and elsewhere in the Mediterranean region. It is said to consist in heating the finely ground phosphate rock to $600^{\circ}-700^{\circ} \mathrm{C}$. with a mixture of calcium, magnesium, and sodium carbonates. The calcined mass is then moistened and diluted with earth or sand until the phosphoric acid content is about 20 per cent. The product, "tetraphosphate," is said to be equal to the ordinary superphosphate in fertilizing power and also cheaper to produce. The beneficial results from the use of the "tetraphosphate" as manufactured in Italy have been questioned by certain chemists. If on further investigation the merits of the product derived by this method are established, the process could readily be put into practice in the Lander district.

\footnotetext{
${ }^{18}$ Methods of manufacture of phosphatic fertllizers are described by W. H. Waggaman and W. H. Fry in U. S. Dept. Agr. Bull. 312, 1915.
} 



\section{INDEX}

Agriculture in the region. 4-5, 18, 19, 22, 23-24, 25, 28

Amsden formation, nature and occurrence of. 9-10 Analyses of phosphate rock.

Bighorn dolomite, nature and occurrence of - . 8-9

Chugwater formation, nature and occurrence

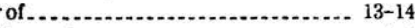

Climate of the region....................... 4-5

Composition of the phosphate rock........... 36

Cretaceous rocks, nature and occurrence of .. 14, 15

"Darby formation," occurrence of ........... 9

Dinwoody formation, age of................. 10

nature of 13

Discovery of phosphate rock in the region. 26,35-36

"Edgewise conglomerate," occurrence of.... S S

Embar formation of Darton, occurrence and divisions of

Faults in the region $17,31-32$

Field work, record of $2-3$

Flathead sandstone, occurrence of............. 7

Gallatin limestone, nature and occurrence of. 8

Geography of the Wind River Mountains ... $3-6$

Geologic map of northeast slope of Wind

River Mountains

18

Glacial drift, occurrence of

Gravel deposits, occurrence of

Gros Ventre formation, nature and occurrence

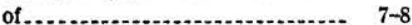

Lower phosphate bed, distribution of 33-34

Madison limestone, nature and occurrence of

Map, geologic, of northeast slope of Wind River Mountains

9

18

Market for Rocky Mountain phosphate rock. 1-2

Mineral resources of the region.

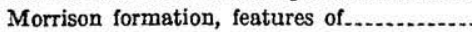

Output of Rocky Mountain phosphate rock.

Phosphoria formation, exposures of, plate showing

...

fossils in

nature and members of ................. 11-13

section of
Pre-Cambrian rocks, features of ............ 6-7

Properties of the phosphate rock........... 35

Red Creek canyon, view toward............ 10

Section in T. 2 S., R. 2 W....................... 20-21

on Baldwin Creek................. 23

on Beaver Creek.............. 32-33

on Deep Creek . ........................... 27

on Little Popo Agie River................. 27

on Mexican Creek............................ 22

on North Fork of Willow Creek.......... 24

on South Fork of Little Wind River..... 11-12

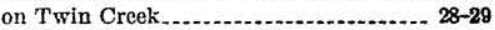

Settlements in the region.................... 5

Sheep Mountain anticline, geologic features of

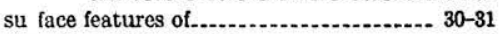

stratigraphy of the region................. 6-17

Streams of the mountain slopes............... 4

Structure of the Wind River Mountains.... 17

Sundance formation, features of............ 14

Tensleep sandstone,nature and occurrence of. 10

Tertiary strata, nature and occurrence of.... 15-16

Tetraphosphate, production and value of.... $\quad 37$

Timber of the region......................... 6

Topography of Wind River Basin.......... 3-4

Township descriptions:

T. 1 N., R. 3 W . . .

T. 30 N., R. 97 W ....................... 30-33

T. 30 N., R. 98 W......... 29-30

T. 30 N., R. 99 W ...... 27-29

T. 31 N., Rs. 97 and $88 \mathrm{~W} . \ldots . . . . . . . . .30-33$

T. 31 N. R. 99 W $25-27$

T. 32 N., R. 100 W......... 23-25

T. 33 N., R. 100 W...................... 22-23

T. 33 N., R. 101 W....................... 21-22

T. 1 S, Rs, 2 and 3 W. 19

T. 2 S., Rs. 1 and 2 W................... 20-21

Trausportation in the region................ $5-6$

Treatment of phosphate rock.................. 36-37

Upper phosphate bed, distribution of...... 34

Wind River Basin, plate showing .......... 10 




